\title{
Cultural valuation and biodiversity conservation in the Upper Guinea forest, West Africa
}

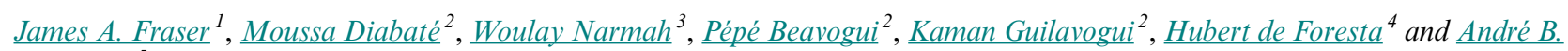 \\ Junqueira $^{5}$
}

\begin{abstract}
The cultural valuation of biodiversity has taken on renewed importance over the last two decades as the ecosystem services framework has become widely adopted. Conservation initiatives increasingly use ecosystem service frameworks to render tropical forest landscapes and their peoples legible to market-oriented initiatives such as REDD+ and biodiversity offsetting schemes. Ecosystem service approaches have been widely criticized by scholars in the social sciences and humanities for their narrow focus on a small number of easily quantifiable and marketable services and a reductionist and sometimes simplistic approach to culture. We address the need to combine methods from each of the "three cultures" of natural science, quantitative social science, and qualitative social science/humanities in conceptualizing the relationship between cultural valuation and biodiversity conservation. We combine qualitative data with forest inventories and a quantitative index of cultural value to evaluate the relationship between cultural valuation and biodiversity conservation in Upper Guinea forest in Liberia, West Africa. Our study focuses on "sacred agroforests," spaces that are associated with Mande macro-language speaking groups such as the Loma. We demonstrate that sacred agroforests are associated with different cultural values compared with secondary forests. Although biodiversity and biomass are similar, sacred agroforests exhibit a different species composition, especially of culturally salient species, increasing overall landscape agro-biodiversity. Sacred agroforests are also shaped and conserved by local cultural institutions revolving around ancestor worship, ritual, and the metaphysical conceptual category "sale." We conclude that to understand the relationship between cultural valuation and biodiversity conservation, interpretivist approaches such as phenomenology should be employed alongside positivist ecosystem service frameworks.
\end{abstract}

Key Words: anthropogenic landscapes; conservation science; cultural heritage; ecosystem services; sacred forests; secondary forests

\section{INTRODUCTION}

The cultural valuation of biodiversity has taken on renewed importance over the last two decades as ecosystem services frameworks have become widely adopted, with the most influential and well-known being presented in the Millennium Ecosystem Assessment (MEA 2005). Conservation initiatives increasingly use ecosystem service frameworks to render tropical forest landscapes and their peoples legible to market-oriented schemes such as REDD+, PES, and biodiversity offsetting in terms of the provisioning, e.g., food and water; regulating, e.g., climate and disease; supporting, e.g., nutrient cycling and pollination; and cultural, e.g., spiritual and recreational, benefits they confer to society (Costanza et al. 1997, MEA 2005, Armsworth et al. 2007, Naidoo et al. 2008, Corbera 2012). Ecosystem service approaches have been widely criticized by scholars in the social sciences and humanities, however, for their narrow focus on a small number of easily quantifiable and marketable services and a reductionist and sometimes simplistic approach to culture (Robertson 2011, Dempsey and Robertson 2012, Kirchhoff 2012, McAfee 2012, Pröpper and Haupts 2014, Schnegg et al. 2014, Winthrop 2014, Plieninger et al. 2015). A major problem is the assumption that cultural services can be quantified, and then be correlated to ecological structures and functions (Daniel et al. 2012, Russell et al. 2013). Although this permits integration with ecological data, it misses the vital point that important dimensions of cultural valuation, e.g., the religious or the sacred, cannot be reduced to ecological objects, empirically observable through positivist methods. More profoundly, the conception of culture as a category of value that is completely separate from the material values of other ecosystem services is a Western, post-Enlightenment, Cartesian phenomenon (Kirchhoff 2012, Pröpper and Haupts 2014). Non-Western peoples often do not separate nature and culture as does the Western lay and scientific thinking behind ecosystem services frameworks (Ingold 2000, Latour 2009, Viveiros de Castro 2012, Descola 2013). Forms of cultural valuation can be fundamentally different to economic valuation, more of a "processual activity of meaning-making" rather than something commensurable to a market assigned monetary value (Pröpper and Haupts 2014, Winthrop 2014, Schnegg et al. 2014). It is now recognized in the conservation literature that understanding the cultural valuation of biodiversity requires interpretivist as well as positivist social science theory and methods (Adams 2007, Sandbrook et al. 2013, Moon and Blackman 2014). Understanding the biocultural relationships through which cultural values shape tropical forest diversity is now increasingly recognized as important for the conservation of both biodiversity and (tangible and intangible) cultural heritage (Gavin et al. 2015). This means investigating the full range of cultural values, from, for example, more utilitarian (Ickowitz et al. 2014) to more symbolic (Dold and Cocks 2012, Cocks and Wiersum 2014). In trying to understand this diversity of cultural valuation, we attempt to overcome problems raised by Kirchhoff (2012) and Turnhout et al. (2013) associated with conflating economic and cultural valuation by combining methods from each of the "three cultures" of natural science, quantitative social science, and qualitative social science/

${ }^{1}$ Lancaster Environment Centre, Lancaster University, Lancaster, UK, ${ }^{2}$ IRAG, CRA, Seredou, Guinea, ${ }^{3}$ College of Agriculture and Forestry, University of Liberia, Capitol Hill, Monrovia, Liberia, ${ }^{4}$ IRD, UMR AMAP, Montpellier, France, ${ }^{5}$ Department of Soil Quality, Wageningen University, Wageningen, The Netherlands 
humanities (Castree 2015). In this paper, we follow Turnhout et al. (2013)'s suggestion that the reductive quantification of cultural values should be accompanied by a broader qualitative contextual investigation of how people "live with" biodiversity in the sense of the role biodiversity plays in society through the meaning(s) that are attributed to it (e.g., Gould et al. 2014, von Heland and Folke 2014, Fraser et al. 2015). We combine transects, an index of cultural valuation of different species, and qualitative data collected using various methods including participant observation and semistructured interviews to examine cultural valuation in relation to biodiversity conservation through a case study of sacred agroforests in the Upper Guinea forest of West Africa.

\section{Cultural valuation and biodiversity conservation in the Upper Guinea forest}

Over time, forms of cultural valuation have shaped a greater abundance of certain species in tropical forests, either through direct propagation or because human activity favors disturbanceadapted species (van Gemerden et al. 2003). The significance of local cultures in shaping the composition and conservation of Africa's tropical rainforests is now well recognized by conservationists, although debates around the scale of historical anthropic influence remain unresolved (Fairhead and Leach 1998, White and Oates 1999, van Gemerden et al. 2003, Bayon et al. 2012, Oslisly et al. 2013, Engone Obiang et al. 2014, Tovar et al. 2014, Vleminckx et al. 2014). In the Upper Guinea forest region of West Africa, identified as a global biodiversity hotspot (Poorter et al. 2004), rapid land-use change driven by logging, rubber plantations, and industrial agriculture has become the biggest threat to the continuing existence of rainforests (Norris et al. 2010). Since the beginning of the 19 th century, up to $470,000 \mathrm{~km}^{2}$ of tropical forest has been cleared (Sayer et al. 1992, Poorter et al. 2004). Liberia has the greatest area coverage of Upper Guinea forest, with some $41,238 \mathrm{~km}^{2}$ or $37.7 \%$ of historic forest cover still remaining (Poorter et al. 2004).

Despite deforestation now being a major threat, much of northwestern (hereafter, NW) Liberia's tropical forest biodiversity appears to have been shaped by long-term anthropogenic influences - indigenous peoples have historically been "builders of forests" (Fairhead and Leach 1996, 1998, Kandeh and Richards 1996) - through biocultural relations with different species entailing forms of cultural valuation. In many localities of NW Liberia, it is not unusual for the only exemplars of mature or primary rainforest species to be found in anthropogenic forest islands around towns, along paths, or at the sites of old towns. Hence, apparently natural forest landscape is often composed of old fallow, historically disturbed through shifting cultivation but with largely unmanaged succession (Fairhead and Leach 1998). One striking feature of such landscapes are "sacred groves." Found on all habitable continents, sacred groves are of ritual and religious importance to particular cultures that in turn confer protection to the culturally valuable tree species they harbor (Gadgil and Vartak 1974, Lebbie and Guries 1995, Byers et al. 2001, Chouin 2002, 2009, Campbell 2005, Bhagwat and Rutte 2006, Sheridan and Nyamweru 2008).

The research presented in this paper focuses on a regionally specific example of this phenomenon, which we term "sacred agroforests" (SA), in the Upper Guinea forest of West Africa. SA are located at the sites of ruined towns belonging to Mande macro-language speaking groups who have occupied the region for more than 500 years (Brooks 1989). Owing to considerable cultural continuity in the region, despite historic and recent wars, current populations are normally descendants of the historical occupants of these towns, and are conferred tenurial rights by ritualized relationships with their ancestors (Fraser et al. 2015). We focus on one group in particular, the Loma. For the Loma, like other Mande speakers and many other societies of subSaharan Africa (Fortes 1965, Calhoun 1980), ancestors are present and have social roles in the world of the living. This reflects the wider tendency in sub-Saharan Africa for the religious and the social to be fundamentally intertwined (Bloch 2008). It is through relationships with ancestors that Loma descendants can access land through status and tenurial rights. These sites are both ritually and symbolically associated with ancestors through graves and certain trees. Ownership normally lies with the male head of a single family within the population of descendants. SA are sometimes used by gender-specific initiation societies (Poro for men, Sande for women), and for ritual and religious activities including divinations and sacrifice to protect individuals and groups (Little 1965, 1966, Leopold 1991, Hojberg 2007, McGovern 2012). These factors mean that clear cutting and burning these sites is strictly forbidden in customary law, thereby conserving plants and trees growing on them. By contrast, the surrounding natural old fallows are not preserved by any cultural laws and may be cut for shifting cultivation or logging.

Although the sacredness of SA is related to the symbolic presence of ancestors, their use as agroforests is related to material practices of ancestors. The activities of ancestors transformed the soil through deposition of charred and fresh organic materials at loci of domestic and food processing. These actions created, over time, anthropogenic soils called "African dark earth" (AfDE) that have double to triple the amount of organic carbon, significantly higher $\mathrm{pH}$, cation exchange capacity, and more plant-available nutrients when compared with background Oxisols (Solomon et al. 2016). SA feature a canopy of culturally significant mature rainforest tree species, and a midstory of cocoa (Theobroma cacao), kola (Cola nitida), and various native and exotic fruit trees. AfDE is attractive for planting cocoa in Liberia because upland soils are extremely infertile; this tree crop normally only grows well in this country on fertile but limited lowland soils. Conversely, Côte d'Ivoire and Ghana have a much more diverse mix of upland soils (Jones et al. 2013), making cocoa cultivation much more viable on upland soils in these countries.

The historical-ecological phenomenon of SA in NW Liberia therefore provides an interesting and hitherto unexplored arena within which to examine the role of cultural valuation in shaping and conserving biodiversity. Studies of sacred forests in West Africa have tended to focus on cultural dimensions with less attention to ecological processes (Fairhead and Leach 1994, Chouin 2009). Studies of agroforests in West Africa tend to be purely ecological and lack recognition of the legacy effects of historical human agency on current species abundance (Oke and Odebiyi 2007, Sonwa et al. 2007, Bisseleua and Vidal 2008, Correia et al. 2010), despite the fact that the distribution of several species found in the agroforests reported in these studies is heavily influenced by historical cultural practices. Forests on anthropogenic soils in Africa, meanwhile, have not been 
Fig. 1. Location of Wenwuta in Liberia (inset top left), and the sacred agroforests and old fallows sampled in the vicinity of Wenwuta. The areas of sacred agroforests and settlements were mapped with GPS in collaboration with local people.
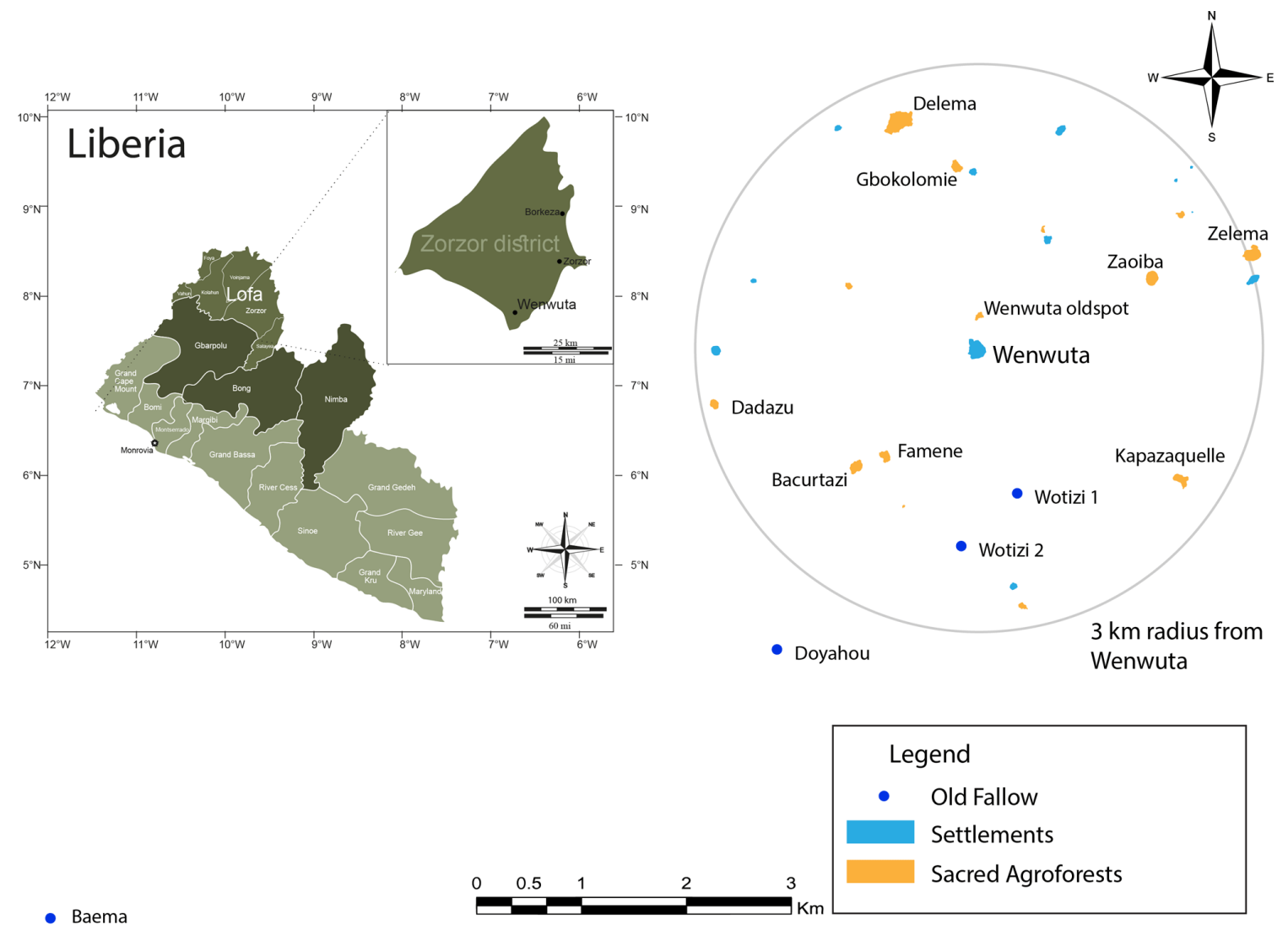

described, and only a handful of studies describe such phenomena in South America (Paz-Rivera and Putz 2009, Junqueira et al. 2010, Fraser et al. 2011a,b, Quintero-Vallejo et al. 2015).

This article and the research it draws on aim to understand the relationship of cultural valuation to biodiversity conservation in the context of SA. First, we carried out a regional survey to determine the extent and typology of SA in NW Liberia. Second, we conducted a case study drawing on participant observation and open interviews to investigate how the cultural values as processes shape natural resource management practice. Third, we compared the ecological characteristics of the vegetation (density of individuals, basal area, species richness, floristic composition) of SA with unmanaged 45-65-year-old fallows (OF). We use OF as a baseline for our comparisons because although they are anthropogenic forests to some degree, they are more similar to natural old-growth forests because they are largely unmanaged. Fourth, we employ an index of cultural valuation to quantify utilitarian and symbolic cultural valuation of different species. Based on a prior literature review and initial observations, we formulated the following research questions:

1. How widespread are SA in NW Liberia?

2. What role do social or religious institutions play in conserving SA?
3. How does the species composition and cultural valuation of SA compare with that of OF?

\section{CASE STUDY AND METHODS}

\section{Regional survey}

To assess the frequency and distribution of SA we conducted an initial regional survey in four counties of NW Liberia: Gbarpolu, Bong, Lofa, and Nimba (Fig. 1, Appendix 1). We selected these counties and the areas visited within them based on descriptions of regions that were heavily populated during the 19th century (Fairhead et al. 2003) that we assumed would have the most prevalent anthropic influence and therefore the greatest area coverage of SA. During our regional survey we asked community leaders how many SA there were in the vicinity of their town or village, and visited the most easily accessible one at each community. In total we visited 83 different localities and at 51 of them we found at least one SA, 94 in total (Appendix 1). It emerged that the local term for SA is "old town spot," confirming that locals are well aware of the anthropogenic origins of these spaces.

Case study selection and participatory mapping of sacred agroforests

Following the initial survey, Wenwuta, a Loma settlement in the southern Zorzor district of Lofa County, NW Liberia (Fig. 1), and its surrounding landscape, were selected for an in-depth case 
study because this relatively remote area is characterized by a high degree of cultural continuity when compared with other regions of NW Liberia. We sought such an area because we wanted to investigate the relationship of cultural valuation to biodiversity conservation away from areas of rapid land use change closer to urban centers. The region has an average rainfall of $2900 \mathrm{~mm}$ (majority of rainfall occurs between July and November) and is capable of supporting wet evergreen forest (Poorter et al. 2004), although today there is no true old-growth forest in a landscape long dominated by rice fields, fallows, and anthropogenic forests (M. Diabaté, personal observation). The geomorphology of the landscape is characterized by low rolling hills that form a hill to valley continuum, within which three major physio-hydrographic positions are distinguished by their soil and the source of water for cultivation. These are pluvial (hilltop, cultivation reliant on precipitation), phreatic (hillside, groundwater from high water table), and fluvial (valley bottom water from surface flow, i.e., run-on and flooding by streams). Natural soils at the top of the toposequence are typically infertile and highly leached Oxisols or Ultisols, whereas those toward the bottom are more fertile Inceptisols and Entisols (Andriesse and Fresco 1991). Wenwuta is a settlement of $\sim 250$ people and around 2.5 ha in size. $C^{14}$ dating shows the town was founded between 1670 and 1682 (Solomon et al. 2016). To estimate the extent of SA around the settlement, in collaboration with locals we GPS-mapped all SA within a 3$\mathrm{km}$ radius of Wenwuta (Fig. 1), which was the area that they knew best and we had easiest logistical access to. This encompasses the entire Wenwuta territory and extends into that of neighboring settlements.

\section{Forest inventories and soil characterization of sacred agroforests and old fallows}

Based on the participatory mapping in collaboration with locals, we chose nine patches of SA and four patches of OF to establish transects for forest inventories (Appendix 2). In each SA, we established between one and five "variable area" transects following Sheil et al. (2003), depending on the size of the patch, resulting in a total of 28 transects. In OF, we established between three and seven transects per patch, in total 21 transects. (Fig. 1, Appendix 2). We did more transects in SA than OF for two reasons: first, owing to the difficulty of finding OF within the area of study, and second, because SA were the focus of study, and their biodiversity is less well understood than that of OF in the region. Transects were based on a 40-m transect line, along which four cells with a length of $10 \mathrm{~m}$ and a variable width were delimited on both sides and perpendicular to the line (eight cells thus making up a sample-plot). Three size-classes of trees were sampled:

$$
\begin{aligned}
& \text { - large trees }\left(\mathrm{DBH}>20 \mathrm{~cm} ; \mathrm{L}_{\max } 20 \text { meters, } \mathrm{L}_{\min } 15\right. \text { meters), } \\
& \text { - medium trees }\left(\mathrm{DBH}>5,<20 \mathrm{~cm} ; \mathrm{L}_{\max } 15 \text { meters, } \mathrm{L}_{\min } 10\right. \\
& \text { meters), } \\
& \text { - tree seedlings }\left(\mathrm{DBH}<5 \mathrm{~cm} ; \mathrm{L}_{\max } 5 \text { meters, } \mathrm{L}_{\min } 2.5\right. \text { meters) }
\end{aligned}
$$

In each cell, for each size class, the five trees closest to the transect line were recorded. If no tree was encountered up to a fixed minimal distance $\left(\mathrm{L}_{\text {min }}\right)$, the cell was tallied as empty and structural parameters (tree density and basal area) for this cell were counted as zero; if less than five trees were encountered up to the maximal distance $\left(\mathrm{L}_{\max }\right)$, the sampling stopped and density was estimated from the number of trees recorded and the maximal distance; if five trees were encountered before the maximal distance, the distance to the line of the fifth tree was recorded and used to estimate tree density (Sheil et al. 2003). For each size-class, a maximum of 40 sampled trees per plot could thus be obtained. Because the number of sample trees per plot varied, to make data on species richness comparable between transects we calculated a species richness index provided by $Z=\log$ (species counts) $/ \log$ (stem counts), following Sheil et al. (2003).

To characterize the soil under SA, we took one soil sample at 0 $15 \mathrm{~cm}$ depth from each of the eight cells in each transect. These were then mixed to create a single composite sample for each transect in the SA. Samples were taken to Cornell Nutrient Analysis Laboratory, and were analyzed for chemical properties (aluminium, phosphorous, copper, zinc, manganese, calcium, lead, potassium, sulphur, iron), organic matter content and $\mathrm{pH}$ (Appendix 3). A separate study showed that the upland soils in the region were uniformly Oxisols (Solomon et al. 2016). Although we did not collect soil samples under OF, we examined in situ a sample taken in each transect to confirm that the OF were located on yellowish/red Oxisols.

\section{Cultural dimensions of sacred agroforests}

To understand the processes by which the Loma value, interact with, and conceive of their environment we used unstructured and semistructured interviews and oral histories $(n=64)$, focus group discussions, participant observation, and transect walks (Cotton 1996) during nine months of fieldwork in Liberia. These methods were contextualized within in-depth ethnography during five months' residence in Wenwuta. In all types of interviews we sought to balance numbers of male and female, youth and elder informants.

To quantify the cultural values associated with species in SA and $\mathrm{OF}$, we used a freelisting technique (a type of cultural domain analysis, see Bernard 2011). We interviewed 116 randomly selected individuals at Wenwuta, surrounding villages, and at the town of Borkeza (Fig. 1). These other locations were selected because of the presence of SA and communities with long histories of interaction with them. We asked each individual the following questions: (1) Which trees can you see when you are in an old town spot (SA)?; (2) Which trees can you see when you are in an OF? We then used the Cognitive Salience Index, proposed by Sutrop (2001) to measure species' cultural salience, which we used as an index of cultural valuation. This index uses free-listing data to elicit and rank the members of a certain cultural domain (in our case: SA and OF). The general idea is that terms (i.e., ethnospecies, that is, different kinds of plants and trees as perceived by locals) that are mentioned more frequently (i.e., in more interviews) and earlier (i.e., among the first terms to be mentioned in each interview) are more "culturally salient" (Quinlan 2005) and therefore have a higher value for the index. Our cultural salience index includes both utilitarian (since most useful plants tend to be mentioned more frequently,) and spirituall symbolic (since some plants that are culturally salient might not have a high utilitarian value) values (Reyes-García et al. 2006). It provides a means to quantify cultural valuation that provides reliable data whilst being relatively quick and easy to conduct interviews (Quinlan 2005). 
Local names for the trees were linked with their scientific equivalents by regional expert botanists Diabaté, Beavogui, and Guilavogui. We then calculated a cultural salience index (adopted from Sutrop 2001) of each tree species using this formula:

$\mathrm{CS}=\mathrm{F} /\left(\mathrm{N}^{*} m \mathrm{P}\right)$

where: $\mathrm{CS}=$ cultural salience index, $\mathrm{F}=$ frequency (\# of people who cited the species), $\mathrm{N}=$ number of people interviewed, $m \mathrm{P}=$ mean order in which the species was mentioned in the lists (or mean "rank" of the species; Sutrop 2001). Using the data obtained in the floristic inventories, we then calculated the average cultural value per tree in each transect and per transect, which were compared between SA and OF.

To compare SA and OF in terms of vegetation structure (density of individuals, basal area), species richness, and cultural valuation index, we used analyses of variance (ANOVA). To visualize differences between SA and OF with regard to their floristic composition, we used an ordination technique (nonmetric multidimensional scaling - NMDS) based on the Bray-Curtis dissimilarity. To test the statistical significance of the difference in species composition between $\mathrm{SA}$ and $\mathrm{OF}$, we used a nonparametric multivariate analysis of variance (MANOVA) with 1000 permutations. All statistical analyses were performed with the $\mathrm{R}$ statistical software using the vegan package (Jari Oksanen et al. 2016).

\section{RESULTS}

\section{Regional survey and coverage estimates}

Open interviews and oral histories conducted during the initial survey indicate that SA exhibit the same fundamental characteristics (that we describe at length below) among Kpelle, Mano, and other speakers of languages belonging to the same Mande macro family as the Loma, all of whom share similar cultural and ritual practices. Clearing and burning these spaces is forbidden under customary law because these sites feature ancestors' graves and certain trees tied to living individuals, neither of which may be disturbed. At the site of old towns, this sacredness allows the continuing existence of mature trees within these spaces while allowing the planting of shade-tolerant economic tree crops such as kola, native to West Africa (Ford 1992), cocoa, native to South America and cultivated in West Africa from the 40s and 50s (Westphal 1987), and coffee (Coffea canephora), native to West Africa. Our participatory GPS mapping within a $3-\mathrm{km}$ radius of Wenwuta ( 2827 ha; Fig. 1) shows that SA cover 18.6 ha of the landscape surrounding the settlement. Given the wide historical distribution of Mande speaking peoples, it seems reasonable to conclude that SA are widespread throughout the Upper Guinea forest of NW Liberia and southern Guinea (Fairhead and Leach 1994, Fairhead et al. 2003), and Sierra Leone as well (Leach 1994, Frausin et al. 2014).

\section{Cultural processes shaping sacred agroforests}

Our interviews and oral histories at Wenwuta and during the wider regional survey revealed that SA are cultural spaces located on the sites of old towns (Appendices 1 and 2), characterized by the presence of ancestors and graves. Ancestors, supernatural beings, and ritual artefacts such as shrines, masks, divinatory media, fetish objects, and herbal medicine are expressed in the concept of sale (expressed in Liberian English as "medicine";
Hojberg 2007, McGovern 2012). We found that that in SA, ancestors and some trees are seen as being endowed with this metaphysical power. The head of the Wenwuta Poro society informed us that certain trees are sale, although one must be familiar with particular sale properties or powers associated with different trees to exploit them for ritual purposes. The Loma explained that the presence of ancestors is manifest in gravestones and also in individual trees that are linked to the living and the dead. Kola trees at SA are often related to living individuals, i.e., they were planted to commemorate the birth of an individual, or other significant events (Ford 1992). One local man explained, "our forefathers moved and planted tree crops for memory. Nobody can make farm on old spots [SA], they still bury people there. When a child is born a kola tree is planted, which is then protected. These are still planted in old town spots or adjacent to them." Cotton (Ceiba pentandra) trees at these sites are also protected. They are said by elders to have once been planted in lieu of gravestones. This in turn imbues mature Ceiba with an ancestral significance.

Owing to this cultural valuation of SA, the cutting and burning of trees is forbidden, but these areas are still used for the cultivation of tree crop species, which can be done without disturbing large, mature emergent rainforest species, and without the need for burning. The Loma recognize that the AfDE that is associated with SA permits cocoa and kola cultivation on upland soils, which is otherwise difficult on highly infertile yellowish red Oxisols that dominate in Liberia ${ }^{[1]}$. A local chief explained, "I brought cacao here in $1964 \ldots$ when we arrived we tried planting cacao everywhere but it did not grow. I planted cacao in the red soil, after 20 years it did not bear fruit. It only grows in the lowland, on old town spots, and around the town... Kola also needs good soils to produce well, so it is good to plant it in the old town spot [SA]."

We found that the settled life of Loma and by extension other Mande groups over time results in a mosaic of SA. A female elder explained, "we plant trees around villages and towns, cocoa; coffee; kola and cotton trees on graves, but after time they get big and the place gets cold and dark. We are prevented by our customary law from cutting the kola and cotton trees, so people decide to move. The town space is then planted with cocoa, kola and other trees, and it becomes an old spot, where people still come for meetings, to gather crops and to bury our dead." Therefore, the physical production or "domestication" of space by the Loma, follows an arc through time from the initial clearance of forest and establishment of the town-space, decades or even centuries of daily domestic activities, and the spatial and temporal dynamics of the planting and management of tree crops and other trees, forest regrowth, and the eventual abandonment of spaces as a living area (Fraser et al. 2014). In this final stage, the surrounding forest island makes the town "too cold," referring to a phenomenon where forest growth over time makes the town "colder," which is associated with a growing power of ancestors and also malevolent spirits, leading to the need to establish a new town in a safer space (McGovern 2012). The abandoned townspace then becomes protected precisely because of the traces of the former settlement, the presence of graves, cotton trees and kola linked to the living. Over the long term therefore, inhabitation of the Upper Guinea forest by Mande speaking peoples creates culturally valuable areas of anthropogenic forest. 
Table 1. Analysis of variance (ANOVA) for the parameters measured in transects established in sacred agroforests $(\mathrm{n}=29)$ and old fallows $(n=21)$ in Northwestern Liberia. Values shown are means \pm their standard deviation.

\begin{tabular}{|c|c|c|c|c|c|c|}
\hline \multirow[t]{2}{*}{ Strata } & \multirow[t]{2}{*}{ Variable } & \multirow[t]{2}{*}{ Unit } & \multirow[t]{2}{*}{ Sacred Agroforests } & \multirow[t]{2}{*}{ Old Fallows } & \multicolumn{2}{|c|}{ Anova } \\
\hline & & & & & $\mathrm{F}$ & $\mathrm{p}$ \\
\hline \multirow[t]{4}{*}{ Seedlings } & Density & \#ind/ha & $3630 \pm 2109$ & $9782 \pm 3557$ & 57.18 & 0.000 \\
\hline & Species richness & $\mathrm{Z}$ (index) & $0.71 \pm 0.05$ & $0.73 \pm 0.06$ & 2.49 & 0.121 \\
\hline & Cultural Salience Index (per ha) & CS/ha & $136.8 \pm 62.1$ & $124.8 \pm 44.4$ & 0.57 & 0.456 \\
\hline & $\begin{array}{l}\text { Cultural Salience Index (per } \\
\text { individual) }\end{array}$ & CS/ind & $0.044 \pm 0.021$ & $0.014 \pm 0.005$ & 41.63 & 0.000 \\
\hline \multirow[t]{5}{*}{ Middle } & Density & \#ind/ha & $985 \pm 465$ & $676 \pm 170$ & 8.38 & 0.006 \\
\hline & Species richness & $Z$ (index) & $0.31 \pm 0.2$ & $0.76 \pm 0.05$ & 103.82 & 0.000 \\
\hline & Cultural Salience Index (per ha) & CS/ha & $193.1 \pm 108.9$ & $6.2 \pm 3.3$ & 61.50 & 0.000 \\
\hline & $\begin{array}{l}\text { Cultural Salience Index (per } \\
\text { individual) }\end{array}$ & CS/ind & $0.191 \pm 0.034$ & $0.009 \pm 0.004$ & 583.89 & 0.000 \\
\hline & Basal Area & $\mathrm{m}^{2} / \mathrm{ha}$ & $8.4 \pm 3.7$ & $5.5 \pm 1.4$ & 11.01 & 0.002 \\
\hline \multirow[t]{5}{*}{ Upper } & Density & \#ind/ha & $172 \pm 77$ & $209 \pm 33$ & 4.04 & 0.050 \\
\hline & Species Richness & $\mathrm{Z}$ (index) & $0.74 \pm 0.1$ & $0.78 \pm 0.06$ & 3.40 & 0.072 \\
\hline & Cultural Salience Index (per ha) & CS/ha & $9.4 \pm 4.4$ & $5 \pm 3.1$ & 15.50 & 0.000 \\
\hline & $\begin{array}{l}\text { Cultural Salience Index (per } \\
\text { individual) }\end{array}$ & CS/ind & $0.057 \pm 0.022$ & $0.023 \pm 0.013$ & 37.80 & 0.000 \\
\hline & Basal Area & $\mathrm{m}^{2} / \mathrm{ha}$ & $35.5 \pm 22.7$ & $37.8 \pm 10.2$ & 0.18 & 0.669 \\
\hline
\end{tabular}

This system, however, is under threat from a generational shift in cultural valuation. Youth across NW Liberia participated in the recent (1990-2005) war, which accelerated already existing processes of change wherein youth begin to challenge various aspects of the Loma worldview, including the sacredness of SA, i.e., that they should not be cleared for annual crop production (Fraser et al. 2015). This is demonstrated in our survey that found that when SA were slashed, it was often by youth in violation of their elders' wishes. This was particularly acute in Nimba County, the cradle of the war, where youth had greatest participation in armed conflict (Appendix 1).

\section{Comparing sacred agroforests and old fallows}

Sacred agroforests and old fallows differed in several of the vegetation parameters that we analyzed (Fig. 2, Table 1). The species richness index tended to be lower in SA than in OF for all strata, but this difference was statistically significant only for the middle strata (Table 1, Fig. 3). The greater disturbance and management intensity to which SA have historically been subject may reduce the number of species in the community, favoring a limited number of species of particular cultural value. This is clearly seen in cacao, for example, a species highly valued and intensively managed that dominates the understory in many patches of SA, particularly at the middle strata. Despite this more intensive management, however, our results show that the upper strata and the seedling strata of SA can maintain a comparable number of species with OF. The density of seedlings was significantly higher on OF than on SA, while the density of trees in middle strata was higher in SA than in OF (Table 1, Fig. 2). Similar to the pattern observed for species richness, the lower density of seedlings in SA can be due to the removal of seedlings from nonuseful species, but once these species are favored, they can occur in high densities at the middle and upper strata.

Our index of cultural valuation showed that SA are of higher overall cultural (utilitarian and symbolic) value to the Loma than OF. This is supported by our finding that the average cultural valuation indices per individual and per hectare were significantly
Fig. 2. Nonmetric multidimensional scaling (NDMS) showing differences in floristic composition between sacred agroforests (SA) and old fallows (OF) in different strata: seedlings, trees with $5<\mathrm{DBH}<20 \mathrm{~cm}$ (middle strata) and trees with $\mathrm{DBH}>$ $20 \mathrm{~cm}$ (upper strata). Each point in the graph represents a transect, and distances between points are proportional to their biological dissimilarity, calculated with the Bray-Curtis index.

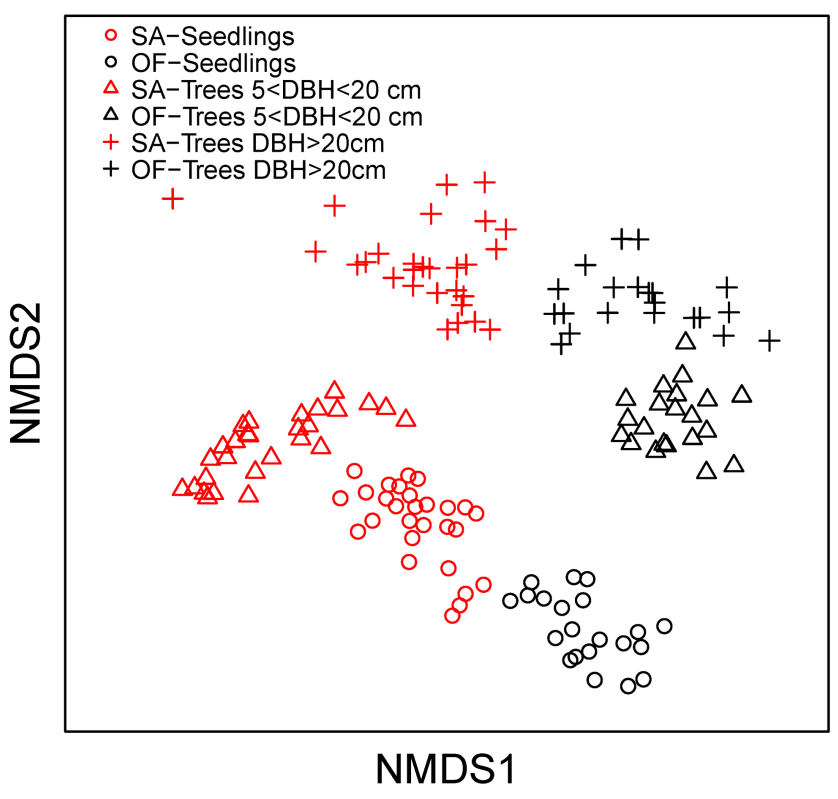

higher in SA for trees in the middle and upper strata, when compared to OF. For seedlings, however, it was higher only when calculated per individual (and not per hectare; Table 1, Fig. 3). This shows that the historical and current management of SA favors the occurrence of species that are of high cultural importance to local people. The lack of difference for seedlings 
is probably the result of the regeneration of these useful species together with species that regenerate naturally during secondary succession. We found that basal area was more heterogeneous and significantly higher in SA than in OF in the middle strata, but in the upper strata it was slightly higher in OF than in SA (although not statistically significant; Table 1, Fig. 3). This is likely the result of the occurrence of useful species in high densities in SA, particularly in the middle strata. The large variation in basal area in SA is likely due to a more heterogeneous land-use history of these areas when compared with OF. These results indicate that SA can have biomass values comparable to those of OF.

Fig. 3. Boxplots showing comparisons between sacred agroforests (SA, white boxes) and old fallows (OF, grey boxes) regarding (A) species richness index (Sheil et al. 1999), cultural salience index [per individual (B) and per hectare (C)], density of individuals (D), and basal area (E) for three vegetation strata: lower ("low"), middle ("mid") and upper ("up"). For our definition of the species richness index, the cultural salience index, and the vegetation strata see section "Case study and methods."
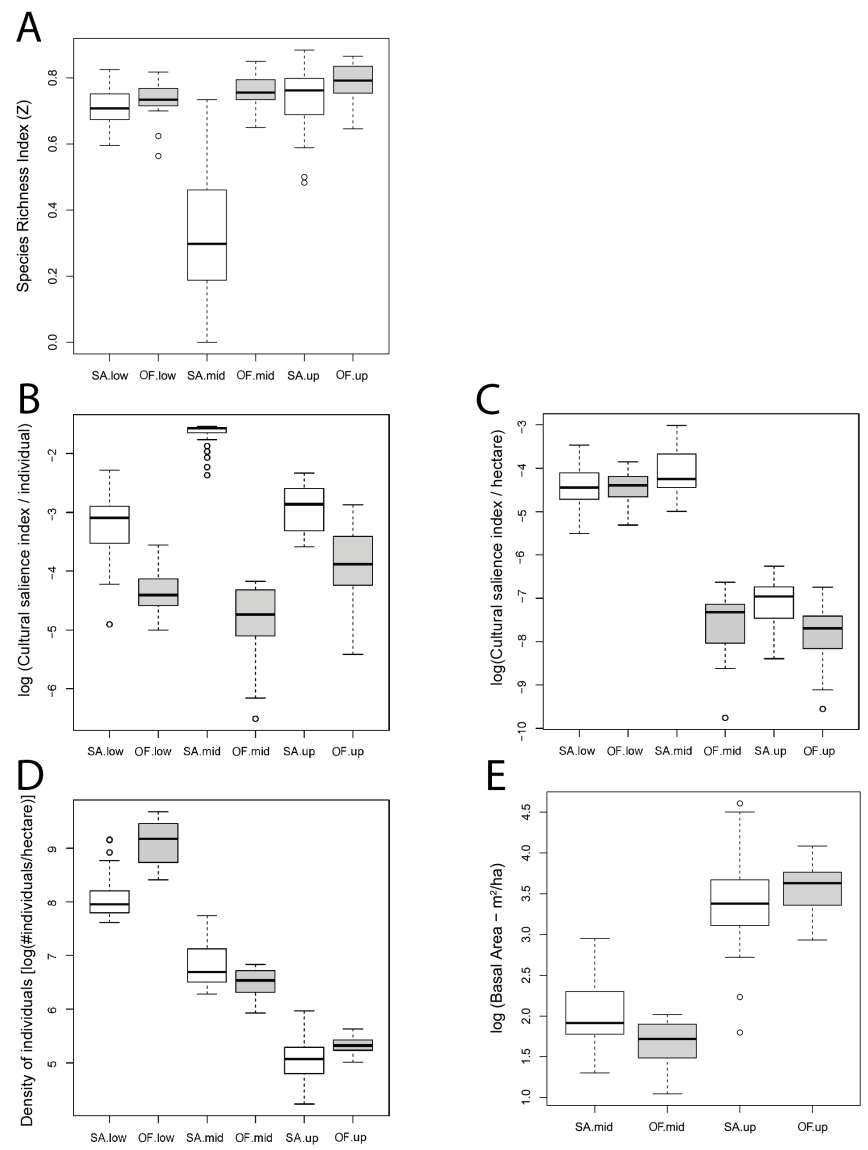

The floristic composition was clearly different between SA and OF for seedlings (NPMANOVA $F=16.08 ; p=0.001$ ), for trees in the middle strata $(F=48.09 ; \mathrm{p}=0.001)$, and for trees in the upper strata $(F=14.13 ; p=0.001 ;$ Fig. 3$)$. The NMDS ordination also shows that the difference in floristic composition between $\mathrm{SA}$ and OF tends to be larger for trees than for seedlings (Fig. 2).
This indicates that species that occur in OF regenerate in the understory of SA but do not reach maturity, either because they are not adapted to that specific environment or because they are removed through management. Figure 2 also shows that in OF the difference between the composition of seedlings and trees is greater than in SA. This shows that, although species composition will likely change with time in both environments, future composition on SA will tend to stay closer to the current composition than will OF.

\section{DISCUSSION AND CONCLUSIONS}

The relationship of cultural valuation to biodiversity conservation is often examined through single disciplinary lenses, leading to partial views and incommensurability between them. We have attempted to overcome these shortcomings by combining methods from each of the three cultures of natural science, quantitative social science, and qualitative social science/ humanities to show the distribution and cultural valuation of SA, their relationship to OF, and the ways in which social institutions mediate the management of these spaces. In this concluding section, we reflect on how successful our combination of different methods and data sets was in addressing our research questions, and their broader utility in exploring the relationship between cultural valuation and biodiversity conservation.

Our first research question sought to establish the extent of the hitherto undescribed phenomenon of SA in NW Liberia. This was the most straightforward in terms of the question and methods, i.e., oral histories and GPS points, yet the most time consuming owing to difficulty of travel both by car and on foot. Our regional survey, interpreted in the light of 19th and 20th century historical descriptions, found that SA are common features of the landscape in northwestern Liberia. Because it relied on local knowledge of old town spots (the local term for $\mathrm{SA}$ ) we consider the findings to be reliable and the sample size to be big enough to support the finding that SA are widespread in the Upper Guinea forest and therefore potentially providing an important role in biodiversity conservation, along with tangible and intangible cultural heritage values. In Madagascar, for example, culturally protected small islands of forest have been shown to be essential for maintaining ecosystem services (Bodin et al. 2006). We found locals to be well aware that the fertility of AfDE permits and/or improves the production of tree crops, particularly cocoa, which, during our regional survey, we did not observe growing outside patches of AfDE or naturally fertile lowland soils.

Our second research question sought to examine and explain the role of social or religious institutions in conserving SA. We drew on a range of ethnographic methods from qualitative social science and humanities. This revealed the cultural processes through which both SA as places and individual species within them are valued and how this valuation shapes their conservation. We found that SA were valued as places for initiation society activities and as sites of fertile soil suitable for farming cocoa. In addition, the presence of ancestors in SA, and their manifestation in graves, trees, and belief in sale, is the cultural value of these places that contributes to their conservation. This cultural valuation of place in terms of the presence of ancestors, is significant in legitimating current inhabitants' claims to land tenure. This important form of cultural valuation cannot be 
captured by quantitative approaches (natural or social), and underlines the importance of qualitative investigation. Moreover, some individual plants and trees in these places were valued both for their utilitarian affordances, while others were symbolically valued because they were seen to be imbued with the metaphysical power sale, while yet others were valued because they were understood to be linked to the living people and the dead ancestors.

Our third research question compared species composition and cultural valuation of SA to that of OF. This question was addressed using quantitative methods from natural science and quantitative social science, strictly oriented toward species and ethnospecies respectively, but not toward these spaces as places, as question two did. We found that although SA have biodiversity and biomass comparable to OF, they have a different species composition, not only adding biodiversity to the landscape, but also conserving forest species that are common in SA but rare (or lacking) in OF. Our index of cultural valuation showed that species within SA are of significantly higher cultural value for the Loma when compared to those of OF. Our index did not differentiate utilitarian and symbolic dimensions of cultural valuation; salience may reflect either or both of symbolic and utilitarian values, and the distinction between these kinds of cultural valuation is better explored through qualitative methods, which we attempted to address in question two.

Our approach was successful to the extent that it used methods from each of the three cultures of science in addressing research questions. However, as with most mixed methods research, it did not integrate the methods as such, rather, they remained separate. The first two research questions were addressed through an interpretivist lens using qualitative methods (GPS points aside) with the underlying assumption of a processual or relational world, whereas the final question was addressed by way of a positivist approach using quantitative methods which, although belonging to different disciplinary groupings (natural science and quantitative social science), are similar in terms of underlying assumptions of a world that can be split up and understood in terms of constituent parts.

This brings us to the question of whether a deeper integration of methods from the three cultures of science is a feasible way to advance ecosystem services frameworks. Our conclusion is that, although the two cultures of natural science and quantitative social science are readily compatible, given their shared underlying positivism, it is a much greater challenge to incorporate methods from qualitative social science and the humanities, given their underlying interpretivism. We are hesitant to suggest that, for example, forms of cultural valuation such as sale, or belief in the presence of ancestors, can be incorporated into ecosystem services approaches without losing their fundamental nature. This is because they are part of indigenous ontologies that are radically different to the Western scientific framing that underlies the ecosystem services framework. The issue is that these two ontologies are incommensurate; the incorporation of sale and/or ancestors on their own terms would undermine the positivist assumptions of the ecosystem services framework. Conversely, were these concepts to be incorporated into the ecosystem services framework on its terms they would lose their situated meaning vis-à-vis the lived experience or "lifeworld(s)" of local people(s). Nevertheless, mixed methods approaches do hold potential for cross-fertilization; the use of each distinct approach can potentially improve interpretations of the other, which can foster a more holistic understanding overall.

We started from the idea that studies combining methods from each of the three cultures of science are likely to provide a more multidimensional understanding of tropical forest landscapes. This approach generates more holistic knowledge that takes into account other values in addition to ecological and economic ones. We advocate the use of methods from the three cultures of science to advance discussion on how to better align and design conservation policies with a diversity of cultural values. However, we suggest that it is unlikely that this would be possible within a singular ecosystem services framework. A more realistic alternative would be to continue to situate methods from the two positivist cultures of natural science and quantitative social science within the ecosystem services framework, with the third interpretivist culture of qualitative social science and humanities located within a suitable alternative theoretical framing such as, for example, phenomenology (e.g., Ingold 2000, Willerslev 2004, Harris 2005, Roth 2009, Jackson 2012, Fraser et al. 2014). Therefore, we recommend that the three cultures of science should be used to consider ecosystem services from different positions (see Williams 2014), rather than attempting to integrate these positions and associated methods into a unified framework, because there are limits to the extent that different approaches can be integrated without one or another losing its essence.

In conclusion, we recommend that given the widespread occurrence of SA in the Upper Guinea forest, these cultural forests should be subject to dedicated conservation policies in West African countries, and policies should be sensitive to the cultural values that we have shown to be related to both the formation and conservation of these sites. With regard to cultural valuation, we note that the utilitarian and symbolic cultural values of SA that we revealed can be expressed through ideas of tangible and intangible cultural heritage, which can be used to articulate cultural valuation and biodiversity conservation to a wider audience. Conservation policies should incorporate intangible cultural heritage or symbolic cultural values into their conceptualization of local cultural valuation, along with better known tangible cultural heritage or utilitarian cultural values.

\footnotetext{
${ }^{[1]}$ Rainfall may also be a factor in the infertility of Liberian soils. The country has one of the heaviest annual rainfalls in all of Africa. In the Upper Guinea forest, rainfall decreases from east to west (see Fig. 2 in Bongers et al. 1999), meaning that over millennia the soils have become significantly much more heavily leached than comparative soils in Ghana, where cocoa cultivation is widely practiced on upland soils.
}

\section{Responses to this article can be read online at: http://www.ecologyandsociety.org/issues/responses. php/8738}




\section{Acknowledgments:}

We thank the ESRC for funding (RES-062-23-2310). We thank other members of the collaborative research program from which the research reported in this article derives, including anthropologists James Fairhead and Melissa Leach at the University of Sussex, UK, Kojo Amanor at the University of Legon in Ghana, and Dominique Millimouno at Cabinet Universitaire de Recherches-Actions, Kissidougou, Republic of Guinea, and soil scientists Johannes Lehmann and Dawit Solomon at Cornell University, Søren M. Kristiansen at Aarhus University, Denmark. Our joint work is cited. We thank Jeanette Carter of the University of Liberia for facilitating our research project and officials of the government of Liberia for granting permission to conduct research. We thank Gayflor Kesselie for assistance in fieldwork. We thank Victoria Frausin for assistance with figures. Any errors of fact and judgment rest with the authors.

\section{LITERATURE CITED}

Adams, W. M. 2007. Editorial. Oryx 41(3):275-276. http://dx.doi. org/10.1017/S0030605307004131

Andriesse, W., and L. O. Fresco. 1991. A characterization of ricegrowing environments in West Africa. Agriculture, Ecosystems \& Environment 33(4):377-395. http://dx.doi.org/10.1016/0167-8809 (91)90059-7

Armsworth, P. R., K. M. A. Chan, G. C. Daily, P. R. Ehrlich, C. Kremen, T. H. Ricketts, and M. A. Sanjayan. 2007. Ecosystemservice science and the way forward for conservation. Conservation Biology 21(6):1383-1384. http://dx.doi.org/10.1111/ j.1523-1739.2007.00821.x

Bayon, G., B. Dennielou, J. Etoubleau, E. Ponzevera, S. Toucanne, and S. Bermell. 2012. Intensifying weathering and land use in Iron Age Central Africa. Science 335(6073):1219-1222. http://dx.doi. org/10.1126/science. 1215400

Bernard, H. R. 2011. Research methods in anthropology: qualitative and quantitative approaches. Fourth edition. Altamira Press, Oxford, UK.

Bhagwat, S. A., and C. Rutte. 2006. Sacred groves: potential for biodiversity management. Frontiers in Ecology and the Environment 4(10):519-524. http://dx.doi.org/10.1890/1540-9295 (2006)4[519:sgpfbm]2.0.co;2

Bisseleua, D. H. B., and S. Vidal. 2008. Plant biodiversity and vegetation structure in traditional cocoa forest gardens in southern Cameroon under different management. Biodiversity and Conservation 17(8):1821-1835. http://dx.doi.org/10.1007/ s10531-007-9276-1

Bloch, M. 2008. Why religion is nothing special but is central. Philosophical Transactions of the Royal Society B: Biological Sciences 363(1499):2055-2061. http://dx.doi.org/10.1098/rstb.2008.0007

Bodin, Ö., M. Tengö, A. Norman, J. Lundberg, and T. Elmqvist. 2006. The value of small size: loss of forest patches and ecological thresholds in southern Madagascar. Ecological Applications 16 (2):440-451. http://dx.doi.org/10.1890/1051-0761(2006)016[0440: tvossl]2.0.co;2
Bongers, F., L. Poorter, R. S. A. R. Van Rompaey, and M. P. E. Parren. 1999. Distribution of twelve moist forest canopy tree species in Liberia and Côte d'Ivoire: response curves to a climatic gradient. Journal of Vegetation Science 10(3):371-382. http://dx. doi.org/10.2307/3237066

Brooks, G. E. 1989. Ecological perspectives on Mande population movements, commercial networks, and settlement patterns from the Atlantic Wet Phase (ca. 5500-2500 B.C.) to the present. History in Africa 16:23-40. http://dx.doi.org/10.2307/3171777

Byers, B. A., R. N. Cunliffe, and A. T. Hudak. 2001. Linking the conservation of culture and nature: a case study of sacred forests in Zimbabwe. Human Ecology 29(2):187-218. http://dx.doi. org/10.1023/A:1011012014240

Calhoun, C. J. 1980. The authority of ancestors: a sociological reconsideration of Fortes's Tallensi in response to Fortes's critics. Man 15(2):304-319. http://dx.doi.org/10.2307/2801673

Campbell, M. O. 2005. Sacred groves for forest conservation in Ghana's coastal savannas: assessing ecological and social dimensions. Singapore Journal of Tropical Geography 26 (2):151-169. http://dx.doi.org/10.1111/j.0129-7619.2005.00211.x

Castree, N. 2015. The "three cultures" problem in global change research. EnviroSociety, 9 March. [online] URL: http://www. envirosociety.org/2015/03/the-three-cultures-problem-in-global-changeresearch

Chouin, G. 2002. Sacred groves in history: pathways to the social shaping of the forest landscapes in coastal Ghana. IDS Bulletin 33(1):39-46. http://dx.doi.org/10.1111/j.1759-5436.2002.tb00005. $\underline{\mathrm{X}}$

Chouin, G. 2009. Forests of power and memory: an archaeology of sacred groves in the Eguafo Polity, Southern Ghana (c. 500-1900 A.D. ). Dissertation, Anthropology, Syracuse University, Syracuse, New York, USA.

Cocks, M. L., and F. Wiersum. 2014. Reappraising the concept of biocultural diversity: a perspective from South Africa. Human Ecology 42(5):727-737. http://dx.doi.org/10.1007/s10745-014-9681-5

Corbera, E. 2012. Problematizing REDD+ as an experiment in payments for ecosystem services. Current Opinion in Environmental Sustainability 4(6):612-619. http://dx.doi.org/10.1016/ j.cosust.2012.09.010

Correia, M., M. Diabaté, P. Beavogui, K. Guilavogui, N. Lamanda, and H. de Foresta. 2010. Conserving forest tree diversity in Guinée Forestière (Guinea, West Africa): the role of coffee-based agroforests. Biodiversity and Conservation 19 (6):1725-1747. http://dx.doi.org/10.1007/s10531-010-9800-6

Costanza, R., R. d'Arge, R. deGroot, S. Farber, M. Grasso, B. Hannon, K. Limburg, S. Naeem, R. V. O’Neill, J. Paruelo, R. G. Raskin, P. Sutton, and M. van den Belt. 1997. The value of the world's ecosystem services and natural capital. Nature 387 (6630):253-260. http://dx.doi.org/10.1038/387253a0

Cotton, C. M. 1996. Ethnobotany: principles and applications. Wiley, Chichester, UK.

Daniel, T. C., A. Muhar, A. Arnberger, O. Aznar, J. W. Boyd, K. M. A. Chan, R. Costanza, T. Elmqvist, C. G. Flint, P. H. Gobster, 
A. Grêt-Regamey, R. Lave, S. Muhar, M. Penker, R. G. Ribe, T. Schauppenlehner, T. Sikor, I. Soloviy, M. Spierenburg, K. Taczanowska, J. Tam, and A. von der Dunk. 2012. Contributions of cultural services to the ecosystem services agenda. Proceedings of the National Academy of Sciences 109(23):8812-8819. http:// dx.doi.org/10.1073/pnas.1114773109

Dempsey, J., and M. M. Robertson. 2012. Ecosystem services: tensions, impurities, and points of engagement within neoliberalism. Progress in Human Geography 36(6):758-779. http://dx.doi.org/10.1177/0309132512437076

Descola, P. 2013. Beyond nature and culture. University of Chicago Press, Chicago, Illinois, USA.

Dold, T., and M. Cocks. 2012. Voices from the forest: celebrating nature and culture in Xhosaland. Jacana Media, Johannesburg, South Africa.

Engone Obiang, N. L., A. Ngomanda, O. Hymas, É. Chézeauxl, and N. Picard. 2014. Diagnosing the demographic balance of two light-demanding tree species populations in central Africa from their diameter distribution. Forest Ecology and Management 313:55-62. http://dx.doi.org/10.1016/j.foreco.2013.10.045

Fairhead, J., T. Geysbeek, S. E. Holsoe, and M. Leach. 2003. African-American exploration in West Africa: four nineteenthcentury diaries. Indiana University Press, Bloomington, Indiana, USA.

Fairhead, J., and M. Leach. 1994. Contested forests: modern conservation and historical land use in Guinea's Ziama reserve. African Affairs 93(373):481-512.

Fairhead, J., and M. Leach. 1996. Misreading the African landscape: society and ecology in a forest-savanna mosaic. Cambridge University Press, Cambridge, UK. http://dx.doi. org/10.1017/cbo9781139164023

Fairhead, J., and M. Leach. 1998. Reframing deforestation: global analyses and local realities: studies in West Africa. Routledge, London, UK.

Ford, M. 1992. Kola production and settlement mobility among the Dan of Nimba, Liberia. African Economic History 20:51-63. http://dx.doi.org/10.2307/3601629

Fortes, M. 1965. Some reflections on ancestor worship in Africa. Pages 122-142 in M. F. A. G. Dieterlen, editor. African systems of thought. Oxford University Press for the International African Institute, London, UK.

Fraser, J. A., V. Frausin, and A. Jarvis. 2015. An intergenerational transmission of sustainability? Ancestral habitus and food production in a traditional agro-ecosystem of the Upper Guinea Forest, West Africa. Global Environmental Change 31:226-238. http://dx.doi.org/10.1016/j.gloenvcha.2015.01.013

Fraser, J. A., A. B. Junqueira, and C. R. Clement. $2011 a$. Homegardens on Amazonian dark earths, non-anthropogenic upland, and floodplain soils along the Brazilian Middle Madeira River exhibit diverging agrobiodiversity Economic Botany 65 (1):1-12. http://dx.doi.org/10.1007/s12231-010-9143-y

Fraser, J. A., A. B. Junqueira, N. C. Kawa, C. P. Moraes, and C. R. Clement. 2011b. Crop diversity on anthropogenic dark earths in central Amazonia. Human Ecology 39(4):395-406. http://dx. doi.org/10.1007/s10745-011-9405-Z

Fraser, J. A., M. Leach, and J. Fairhead. 2014. Anthropogenic dark earths in the landscapes of Upper Guinea, West Africa: intentional or inevitable? Annals of the Association of American Geographers 104(6):1222-1238. http://dx.doi.org/10.1080/00045$\underline{608.2014 .941735}$

Frausin, V., J. A. Fraser, W. Narmah, M. K. Lahai, T. R. A. Winnebah, J. Fairhead, and M. Leach. 2014. "God made the soil, but we made it fertile": gender, knowledge, and practice in the formation and use of African dark earths in Liberia and Sierra Leone. Human Ecology 42(5):695-710. http://dx.doi.org/10.1007/ s10745-014-9686-0

Gadgil, M., and V. D. Vartak. 1974. The sacred groves of Western Ghats in India. Economic Botany 30(2):152-160. http://dx.doi. org/10.1007/bf02862961

Gavin, M. C., J. McCarter, A. Mead, F. Berkes, J. R. Stepp, D. Peterson, and R. Tang. 2015. Defining biocultural approaches to conservation. Trends in Ecology \& Evolution 30(3):140-145. http:// dx.doi.org/10.1016/j.tree.2014.12.005

Gould, R. K., N. M. Ardoin, U. Woodside, T. Satterfield, N. Hannahs, and G. C. Daily. 2014. The forest has a story: cultural ecosystem services in Kona, Hawai'i. Ecology and Society 19 (3):55. http://dx.doi.org/10.5751/ES-06893-190355

Harris, M. 2005. Riding a wave: embodied skills and colonial history on the Amazon floodplain. Ethnos 70(2):197-219. http:// dx.doi.org/10.1080/00141840500141287

Hojberg, C. 2007. Resisting state iconoclasm among the Loma of Guinea. Carolina Academic Press, Durham, North Carolina, USA.

Ickowitz, A., B. Powell, M. A. Salim, and T. C. H. Sunderland. 2014. Dietary quality and tree cover in Africa. Global Environmental Change 24:287-294. http://dx.doi.org/10.1016/j. gloenvcha.2013.12.001

Ingold, T. 2000. The perception of the environment: essays on livelihood, dwelling and skill. Routledge, London, UK. http://dx. doi.org/10.4324/9780203466025

Jackson, M. 2012. Lifeworlds: essays in existential anthropology. University of Chicago Press, Chicago, Illinois, USA. http://dx. doi.org/10.7208/chicago/9780226923666.001.0001

Jari Oksanen, F., G. Blanchet, M. Friendly, R. Kindt, P. Legendre, D. McGlinn, P. R. Minchin, R. B. O'Hara, G. L. Simpson, P. Solymos, M. H. H. Stevens, E. Szoecs, and H. Wagner. 2016. vegan: Community ecology package. $R$ package version $2.4-1$. The R Project for Statistical Computing, Vienna, Austria. [online] URL: http://CRAN.R-project.org/package=vegan

Jones, A., H. Breuning-Madsen, M. Brossard, A. Dampha, J. Deckers, O. Dewitte, T. Gallali, S. Hallett, R Jones, M. Kilasara, P. Le Roux, E. Micheli, L. Montanarella, O. Spaargaren, L. Thiombiano, E. Van Ranst, M. Yemefack, R. Zougmoré, editors. 2013. Soil atlas of Africa. European Commission, Publications Office of the European Union, Luxembourg. 
Junqueira, A. B., G. H. Shepard Jr, and C. R. Clement. 2010. Secondary forests on anthropogenic soils in Brazilian Amazonia conserve agrobiodiversity. Biodiversity and Conservation 19 (7):1933-1961. http://dx.doi.org/10.1007/s10531-010-9813-1

Kandeh, H. B. S., and P. Richards. 1996. Rural people as conservationists: querying neo-Malthusian assumptions about biodiversity in Sierra Leone. Africa 66(1):90-103. http://dx.doi. org/10.2307/1161513

Kirchhoff, T. 2012. Pivotal cultural values of nature cannot be integrated into the ecosystem services framework. Proceedings of the National Academy of Sciences 109(46):E3146. http://dx.doi. org/10.1073/pnas.1212409109

Latour, B. 2009. Perspectivism: 'type' or 'bomb'? Anthropology Today 25(2):1-2. http://dx.doi.org/10.1111/j.1467-8322.2009.00652. $\underline{\mathrm{x}}$

Leach, M. 1994. Rainforest relations: gender and resource use among the Mende of Gola, Sierra Leone. Edinburgh University Press, Edinburgh, UK.

Lebbie, A. R. G., R. P. Guries. 1995. Ethnobotanical value and conservation of sacred groves of the Kpaa Mende in Sierra Leone. Economic Botany 49(3):297-308. http://dx.doi.org/10.1007/ $\underline{\text { bf02862349 }}$

Leopold, R. S. 1991. Prescriptive alliance and ritual collaboration in Loma society. Dissertation, Indiana University, Bloomington, Indiana, USA.

Little, K. 1965. The political function of the Poro. Part 1. Africa 35(4):349-365. http://dx.doi.org/10.2307/1157659

Little, K. 1966. The political function of the Poro. Part II. Africa 36(1):62-72. http://dx.doi.org/10.2307/1158128

McAfee, K. 2012. The contradictory logic of global ecosystem services markets. Development and Change 43:105-131. http://dx. doi.org/10.1111/j.1467-7660.2011.01745.x

McGovern, M. 2012. Unmasking the state: making Guinea modern. University of Chicago Press, Chicago, Illinois, USA. http://dx.doi.org/10.7208/chicago/9780226925110.001.0001

Millennium Ecosystem Assessment (MEA). 2005. Ecosystems and human well-being: synthesis. Island Press, Washington, D.C., USA.

Moon, K., and D. Blackman. 2014. A guide to understanding social science research for natural scientists. Conservation Biology 28(5):1167-1177. http://dx.doi.org/10.1111/cobi.12326

Naidoo, R., A. Balmford, R. Costanza, B. Fisher, R. E. Green, B. Lehner, T. R. Malcolm, and T. H. Ricketts. 2008. Global mapping of ecosystem services and conservation priorities. Proceedings of the National Academy of Sciences 105 (28):9495-9500. http://dx.doi.org/10.1073/pnas.0707823105

Norris, K., A. Asase, B. Collen, J. Gockowksi, J. Mason, B. Phalan, and A. Wade. 2010. Biodiversity in a forest-agriculture mosaic - the changing face of West African rainforests. Biological Conservation 143(10):2341-2350. http://dx.doi.org/10.1016/j. biocon.2009.12.032
Oke, D. O., and K. A. Odebiyi. 2007. Traditional cocoa-based agroforestry and forest species conservation in Ondo State, Nigeria. Agriculture, Ecosystems \& Environment 122(3):305-311. http://dx.doi.org/10.1016/j.agee.2007.01.022

Oslisly, R., L. White, I. Bentaleb, C. Favier, M. Fontugne, J.-F. Gillet, and D. Sebag. 2013. Climatic and cultural changes in the west Congo Basin forests over the past 5000 years. Philosophical Transactions of the Royal Society B: Biological Sciences 368 (1625). http://dx.doi.org/10.1098/rstb.2012.0304

Paz-Rivera, C., and F. E. Putz. 2009. Anthropogenic soils and tree distributions in a lowland forest in Bolivia. Biotropica 41 (6):665-675. http://dx.doi.org/10.1111/j.1744-7429.2009.00521.x

Plieninger, T., C. Bieling, N. Fagerholm, A. Byg, T. Hartel, P. Hurley, C. A. López-Santiago, N. Nagabhatla, E. Oteros-Rozas, C. M. Raymond, D. van der Horst, and L. Huntsinger. 2015. The role of cultural ecosystem services in landscape management and planning. Current Opinion in Environmental Sustainability 14:28-33. http://dx.doi.org/10.1016/j.cosust.2015.02.006

Poorter, L., F. Bongers, and R. H. M. J. Lemmens. 2004. West African forests: introduction. Pages 5-14 in L. Poorter, F. Bongers, F. N. Kouamé, and W. D. Hawthorne, editors. Biodiversity of West African forests: an ecological atlas of woody plant species. CABI, Wallingford, UK. http://dx.doi.org/10.1079/9780851997346.0005

Pröpper, M., and F. Haupts. 2014. The culturality of ecosystem services. Emphasizing process and transformation. Ecological Economics 108:28-35. http://dx.doi.org/10.1016/j.ecolecon.2014.09.023

Quinlan, M. 2005. Considerations for collecting freelists in the field: examples from ethobotany. Field Methods 17(3):219-234. http://dx.doi.org/10.1177/1525822x05277460

Quintero-Vallejo, E., Y. Klomberg, F. Bongers, L. Poorter, M. Toledo, and M. Peña-Claros. 2015. Amazonian dark earth shapes the understory plant community in a Bolivian forest. Biotropica 47(2):152-161. http://dx.doi.org/10.1111/btp.12193

Reyes-García, V., T. Huanca, V. Vadez, W. Leonard, and D. Wilkie. 2006. Cultural, practical, and economic value of wild plants: a quantitative study in the Bolivian Amazon. Economic Botany 60(1):62-74. http://dx.doi.org/10.1663/0013-0001(2006) 60[62:cpaevo]2.0.c0;2

Robertson, M. 2011. Measurement and alienation: making a world of ecosystem services. Transactions of the Institute of British Geographers 37(3):386-401. http://dx.doi.org/10.1111/ j.1475-5661.2011.00476.X

Roth, R. 2009. The challenges of mapping complex indigenous spatiality: from abstract space to dwelling space. Cultural Geographies 16(2):207-227. http://dx.doi.org/10.1177/1474474008101517

Russell, R., A. D. Guerry, P. Balvanera, R. K. Gould, X. Basurto, K. M. A. Chan, S. Klain, J. Levine, and J. Tam. 2013. Humans and nature: how knowing and experiencing nature affect wellbeing. Annual Review of Environment and Resources 38 (1):473-502. http://dx.doi.org/10.1146/annurev-environ-012312-110838

Sandbrook, C., W. M. Adams, B. Büscher, and B. Vira. 2013. Social research and biodiversity conservation. Conservation Biology 27(6):1487-1490. http://dx.doi.org/10.1111/cobi.12141 
Sayer, J. A., C. S. Harcourt, and N. M. Collins, editors. 1992. The conservation atlas of tropical forests: Africa. IUCN-The World Conservation Union. Macmillan, London, UK. http://dx.doi. org/10.1007/978-1-349-12961-4

Schnegg, M., R. Rieprich, and M. Pröpper. 2014. Culture, nature, and the valuation of ecosystem services in northern Namibia. Ecology and Society 19(4):26. http://dx.doi.org/10.5751/ es-06896-190426

Sheil, D., M. J. Ducey, K. Sidiyasa, and I. Samsoedin. 2003. A new type of sample unit for the efficient assessment of diverse tree communities in complex forest landscapes. Journal of Tropical Forest Science 15(1):117-135.

Sheridan, M. J., and C. Nyamweru, editors. 2008. African sacred groves: ecological dynamics and social change. James Currey, London, UK.

Solomon, D., J. Lehmann, J. A. Fraser, M. Leach, K. Amanor, V. Frausin, S. M. Kristiansen, D. Millimouno, and J. Fairhead. 2016. Indigenous African soil enrichment as climate-smart sustainable agriculture alternative. Frontiers in Ecology and the Environment 14(2):71-76 http://dx.doi.org/10.1002/fee.1226

Sonwa, D. J., B. A. Nkongmeneck, S. F. Weise, M. Tchatat, A. A. Adesina, and M. J. J. Janssens. 2007. Diversity of plants in cocoa agroforests in the humid forest zone of Southern Cameroon. Biodiversity and Conservation 16(8):2385-2400. http://dx.doi. org/10.1007/s10531-007-9187-1

Sutrop, U. 2001. List task and a cognitive salience index. Field Methods 13(3):263-276. http://dx.doi.org/10.1177/1525822x0101300303

Tovar, C., E. Breman, T. Brncic, D. J. Harris, R. Bailey, and K. J. Willis. 2014. Influence of 1100 years of burning on the central African rainforest. Ecography 37(11):1139-1148. http://dx.doi. org/10.1111/ecog.00697

Turnhout, E., C. Waterton, K. Neves, and M. Buizer. 2013. Rethinking biodiversity: from goods and services to "living with." Conservation Letters 6(3):154-161. http://dx.doi.org/10.1111/ j.1755-263x.2012.00307.x

van Gemerden, B. S., H. Olff, M. P. E. Parren, and F. Bongers. 2003. The pristine rain forest? Remnants of historical human impacts on current tree species composition and diversity. Journal of Biogeography 9:1381-1390. http://dx.doi.org/10.1046/ j.1365-2699.2003.00937.x

Viveiros de Castro, E. 2012. Cosmological perspectivism in Amazonia and elsewhere. Hau: Journal of Ethnographic Theory http://www.haujournal.org/index.php/masterclass/article/ view/72/54

Vleminckx, J., J. Morin-Rivat, A. B. Biwolé, K. Daïnou, J.-F. Gillet, J.-L. Doucet, T. Drouet, and O. J. Hardy. 2014. Soil charcoal to assess the impacts of past human disturbances on tropical forests. PLoS ONE 9(11):e108121. http://dx.doi. org/10.1371/journal.pone.0108121

von Heland, J., and C. Folke. 2014. A social contract with the ancestors - culture and ecosystem services in southern Madagascar. Global Environmental Change 24:251-264. http://dx. doi.org/10.1016/j.gloenvcha.2013.11.003
Westphal, U., M. Clemens, K. Gaesing, U. Grossmann, D. Kunze, and D. Weiskopf, editors. 1987. Baseline survey on smallholders in Nimba County: to facilitate decision taking in project planning. Seminar für Landwirtschaftliche Entwicklung (SLE) Publication No. 109. Fachbereich Internationale Agrarentwicklung, Technische Universität Berlin, Berlin, Germany.

White, L. J. T., and J. F. Oates. 1999. New data on the history of the plateau forest of Okomu, southern Nigeria: an insight into how human disturbance has shaped the African rain forest. Global Ecology and Biogeography 8:355-361. http://dx.doi.org/10.1046/ j.1365-2699.1999.00149.x

Willerslev, R. 2004. Spirits as 'ready to hand': a phenomenological analysis of Yukaghir spiritual knowledge and dreaming. Anthropological Theory 4(4):395-418. http://dx.doi. org/10.1177/1463499604047918

Williams D. R. 2014. Making sense of 'place': reflections on pluralism and positionality in place research. Landscape and Urban Planning 131:74-82. http://dx.doi.org/10.1016/j. landurbplan.2014.08.002

Winthrop, R. H. 2014. The strange case of cultural services: limits of the ecosystem services paradigm. Ecological Economics 108:208-214. http://dx.doi.org/10.1016/j.ecolecon.2014.10.005 
Appendix 1
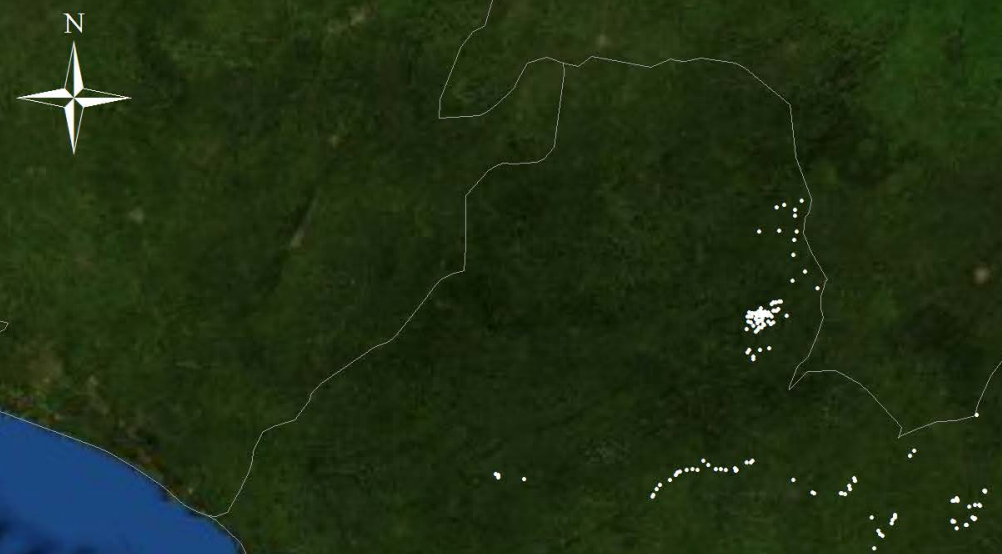

Figure A1.1: Localities surveyed where Sacred Agroforests were found in North Western Liberia 
Table A1.1: Site description and kinds of AfDE encountered during regional survey

\begin{tabular}{|c|c|c|c|c|c|c|c|c|c|}
\hline & $\mathrm{A}$ & $\mathrm{B}$ & c & $\mathrm{D}$ & E & $\mathrm{F}$ & G & $\mathrm{H}$ & 1 \\
\hline 1 & lat. & lon. & County & Language / Clan & Name & Site Description & Currently forming AfDE & Swidden field on & Sacred Agroforest on \\
\hline 2 & & & & & & & surrounding village/town & abandoned AfDE site & abandoned AfDE site \\
\hline 3 & 7.08889 & -9.81751 & Bong & Southern Kpelle & Baletulah & old town spot, planted with rice. & 0 & 1 & \\
\hline 4 & 7.07657 & -9.86948 & Bong & Southern Kpelle & Bosama & old town spot, planted with maize and vegetables. & 0 & 1 & \\
\hline 5 & 7.06638 & -9.87518 & Bong & Southern Kpelle & Boyeta & old town spot, tree crops & 0 & 0 & \\
\hline 6 & 7.10962 & -9.63111 & Bong & Southern Kpelle & Dumah & old town spot with very black earth, in 2 nd year of cultivation, first year was rice, now sugar cane. Various tree crops retained & 0 & 1 & \\
\hline 7 & 7.01911 & -9.94176 & Bong & Southern Kpelle & Faulknero & old town spot with coffee etc., another had been farmed but now fallow & 0 & 1 & \\
\hline 8 & 7.11018 & -9.6156 & Bong & Southern Kpelle & Gaytoi & old town spot, dark soils, tree crops & 0 & 0 & \\
\hline 9 & 7.03329 & -9.92971 & Bong & Southern Kpelle & Gbamokollie-ta & $\begin{array}{l}\text { old town spot with forest, some tree crops. Town surrounded by black middens, has been in the same spot for v long time. population } \\
\text { 1000. middens planted with plantain, orange etc. }\end{array}$ & & 0 & \\
\hline 10 & 7.07843 & -9.86167 & Bong & Southern Kpelle & Gbogbo-ta & $\begin{array}{l}\text { population } 600 . \text { surounded by middens, plantain, cocoa, kola etc. } 4 \text { old spots, } 2 \text { with cacao, kola etc., } 3 \text { was farmed, now fallow, } 4 \text { is a } \\
\text { vegetable garden (Bosama) }\end{array}$ & & & \\
\hline 11 & 7.62699 & -9.57501 & Bong & Gissima Loma & Gbokolomie & Satellite village for Wenwuta, used to be much large. Circular AfDE around village with ring of plantain and tree crops. Population $<100$ & 1 & 0 & \\
\hline 12 & 7.11623 & -9.7795 & Bong & Southern Kpelle & Gbonota & $\begin{array}{l}\text { population 4000, still in old spot, middens. Towns with old spots closeby: Bongay, old spot with cacao, fruits. Belleman, old town spot with } \\
\text { cocao, orange, piata, old spot with cacoa, kola. }\end{array}$ & & & \\
\hline 13 & 7.08921 & -9.67017 & Bong & Southern Kpelle & Gokai & 3 old spots, 1 is tree crops, 2 others see Jaqui and Jaq-old (old spot for Jaqui) & 0 & 0 & \\
\hline 14 & 7.08416 & -9.70181 & Bong & Southern Kpelle & Gwamtayea & 3 old town spots, all with tree crops & 0 & 0 & \\
\hline 15 & 7.08527 & -9.66593 & Bong & Southern Kpelle & Jaiqui & old town spot, center left with tree crops, adjacent areas cultivated with rice \& cassava & 0 & 0 & \\
\hline 16 & 6.99127 & -9.95493 & Bong & Southern Kpelle & Junkar & $\begin{array}{l}\text { old town spot with dark soils, center left with orange, coffee, kola, cacao trees, adjacent field in 2nd year of cultivation with rice, corn, } \\
\text { bulgar wheat, cassava, plantain, bitter ball etc. }\end{array}$ & 0 & 1 & \\
\hline 17 & 6.99915 & -9.95144 & Bong & Southern Kpelle & Kamara & $\begin{array}{l}\text { old town spot with kola etc. Adjacent to village however there was old rubber grove with dark brown soils, locals say no memory of it } \\
\text { being an old spot, but found iron tools there. Planted with rice and corn. No way of knowing if these soils are anthropogenic without } \\
\text { testing }\end{array}$ & & & \\
\hline 18 & 7.08482 & -9.83746 & Bong & Southern Kpelle & Lamanta2 & midden behind village with plantain etc. old town spot tree crops & & 0 & \\
\hline 19 & 7.05057 & -9.89431 & Bong & Southern Kpelle & Lamanta & old town spot, tree crops & 0 & 0 & \\
\hline 20 & 7.11646 & -9.6112 & Bong & Southern Kpelle & Lanyah & hilltop dark earth site, planted in rice + womens crops, kola and cutting trees retained & 0 & 1 & \\
\hline 21 & 7.08735 & -9.71856 & Bong & Southern Kpelle & Leku-ta & 3 old spots, 1 planted with veg, now fallow, $2 \& 3$ cocao, orange etc. & 0 & 0 & \\
\hline 22 & 7.0599 & -10.4872 & Bong & Southern Kpelle & Mopomai & $\begin{array}{l}\text { old Town Spot close to Bopolu, now cleared into two different rice fields. Soils dark and repele with ceramics but not too different to } \\
\text { natural dark brown soils observed in the region. }\end{array}$ & 0 & & \\
\hline 23 & 7.08471 & -9.79908 & Bong & Southern Kpelle & Nyain & middens, old town spot with cacao & 1 & 0 & \\
\hline 24 & & & Bong & Southern Kpelle & Sanoyea & $\begin{array}{l}\text { moved from old town spot in the } 1930 \text { s, which is located on a nearby hill, and the town moved because of water shortage there. The old } \\
\text { spot is planted with tree crops, but rice farming on the hillside. }\end{array}$ & 0 & 0 & \\
\hline 25 & 7.10168 & -9.76273 & Bong & Southern Kpelle & Tayama & old town spot, tree crops & 0 & 0 & \\
\hline 26 & 7.08682 & -9.73622 & Bong & Southern Kpelle & Wayemue & 2 old spots, 1 cacao grove, 2 graveyard & 0 & 0 & \\
\hline 27 & 7.0624 & -10.4869 & Gbarpolu & Multi & Borborta & Old Town spot adjacent to Bopolu town, now with settlement ontop & 1 & 0 & \\
\hline 28 & 7.06557 & -10.4924 & Gbarpolu & Multi & Darkforest & AfDE area under urban Bopolu & 1 & 0 & \\
\hline 29 & 7.07042 & -10.4977 & Gbarpolu & Multi & Goldcamp & Old Town spot adjacent to Bopolu town, cleared for planting with vegetables. & 0 & 1 & \\
\hline 30 & 7.07965 & -10.4707 & Gbarpolu & Loma & Sapema & Town close to Bopolu, with distant old town spot & 0 & 0 & \\
\hline 31 & 7.05212 & -10.3994 & Gbarpolu & & Totoquelle & ttlement, some coffee planted and kola etc., but mainly used for secret society activities & 0 & 0 & \\
\hline 32 & 7.90799 & -9.4584 & Lofa & Multi & Borkeza & $\begin{array}{l}\text { Biggest town visited. Pop 13,900. Before was } 7 \text { villages which joined together to defend themselves during tribal war. These villages have } \\
\text { old town spots with coffee, cocoa, kola atc. Forbidden to make rice farm on old town spots. The town today has a large old town spot } \\
\text { surrounded by AfDE, which was abandoned during the war, and is now being reinhabited by some people, but most of the population has } \\
\text { created a new town spot in an adjacent old plam plantation. While this town has the largest area of AfDE we have encountered, only a } \\
\text { few areas were cultivated, large areas were reserved for inidividuals who were going to reconstruct houses. There were only } 3 \text { proper } \\
\text { gardens in AfDE. } 1 \text { planted with edo, with cacao and coffee behind, } 2 \text { with potato, edo, plantain and aubergine, } 3 \text { with rice, maize and } \\
\text { plantain. }\end{array}$ & & 4 & \\
\hline 33 & 7.82698 & -9.46753 & Lofa & Gissima Loma & Fissebu & We stopped briefly on the way to Borkeza. Old town spot with AfDE is now reinhabited by people, some small kitchen gardens & 0 & & \\
\hline 34 & 7.63972 & -9.5207 & Lofa & Gissima Loma & Gayflor & Village adjacent to Yanzisiy AfDE site. Population 300 & 0 & 0 & \\
\hline 35 & 7.50623 & -9.55309 & Lofa & Barlain Kpelle & Gbonyea & $\begin{array}{l}\begin{array}{l}\text { Population } 3500 \text {. Town is formed from } 5 \text { quarters, each has an old town spot. According to the people each has dark soils and tree crops } \\
\text { We visited one (see Jangay) }\end{array} \\
\end{array}$ & & & \\
\hline 36 & 7.29565 & 9.35579 & Lofa & Barlain Kpelle & Jangay & $\begin{array}{l}\text { This site was abandonded and its inhabitants moved to Gbonyea. It was some } 1.5 \text { hours walk from Gbonyea, including wading across } \\
\text { river. Jangay is on low hill, now covered in old cacao, kola and massive cotton trees. black AfDE underneath and visible walls. }\end{array}$ & tat & & \\
\hline 37 & 7.47639 & -9.60692 & Lofa & Barlain Kpelle & Kollita & $\begin{array}{l}\text { Old town spot on hill } 20 \text { mins fom Kpayakollie. Dark soils + pottery at each edge of ridge. Cocoa, coffee, citrus, and certain useful plants } \\
\text { found at old town spots, such as "medicine pepper." The slopes of the hill, also with dark soils cultivated with rice. }\end{array}$ & 0 & & \\
\hline
\end{tabular}




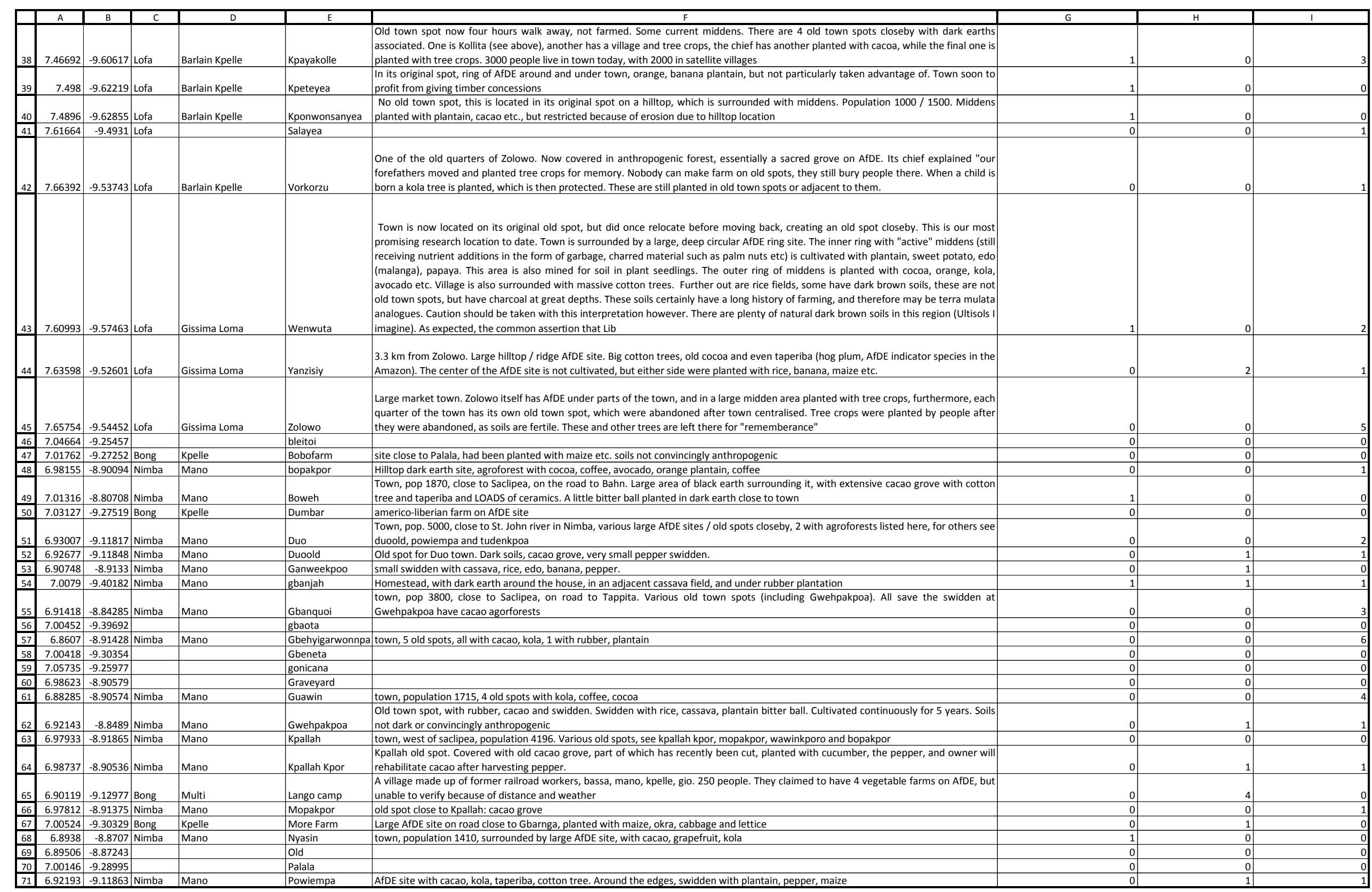




\begin{tabular}{|c|c|c|c|c|c|c|c|c|c|}
\hline 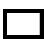 & $\mathrm{A}$ & $\mathrm{B}$ & $\mathrm{c}$ & $\mathrm{D}$ & $\mathrm{E}$ & $\mathrm{F}$ & $G$ & $\mathrm{H}$ & 1 \\
\hline 72 & 6.95813 & -8.86011 & Nimba & Mano & Sanquor & $\begin{array}{l}\text { this site is on close to Saclipea,to the west, town rapidly encroching. Black earths, cocoa groves, larger trees being removed for wood. } \\
\text { ceramics. Large swidden that was cleared in 2008, cultivated with rice, } 2009 \text { with corn, } 2010 \text { with corn. Also some plantain, okra, bitter } \\
\text { ball there }\end{array}$ & & & \\
\hline 73 & 6.906 & -8.92032 & Nimba & Mano & Tengbhin & $\begin{array}{l}\text { town, population 1205, } 3 \text { old spots close to town. } 2 \text { cocao farms, } 1 \text { small swidden with cassava, rice, edo, banana, pepper. See zoazoah } \\
\text { and ganweekpoo }\end{array}$ & 0 & 0 & \\
\hline 74 & 7.04662 & -9.25456 & & & Tomato Camp & & 0 & 0 & 0 \\
\hline 75 & 6.91063 & -9.12581 & Nimba & Mano & Tudenkpoa & $\begin{array}{l}\text { hilltop AfDE site right by st. john river. Center of site cotton trees, cocoa, grapefruit, kola, on the site, cleared for a swidden with mostly } \\
\text { pepper, some plaintain, edo, okra, yam, aubergine, bitter ball }\end{array}$ & 0 & 1 & \\
\hline 76 & 6.86312 & -9.16931 & & & Veg & & 0 & 0 & 0 \\
\hline 77 & 7.13389 & -9.06572 & & & Venn Town & & 0 & 0 & 0 \\
\hline \begin{tabular}{|l|}
78 \\
\end{tabular} & 6.97868 & -8.90227 & Nimba & Mano & Wawinkporo & cassava farm in 2009, agroforest & 0 & 1 & 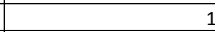 \\
\hline \begin{tabular}{|l|l|}
79 \\
\end{tabular} & 7.15042 & -9.05249 & & & Wolena & & 0 & 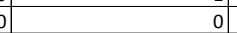 & 0 \\
\hline 80 & 6.85754 & -9.16078 & Bong & Kpelle & Yopea & Town, population 1000.6 old spot, 5 with cocoa, kola, citrus, 1 with vegetables and cocoa & 0 & 1 & 5 \\
\hline 81 & 6.92029 & -9.19782 & Bong & Kpelle & Zebay & large town, with middens around it & 1 & 0 & 0 \\
\hline 82 & 6.96114 & -8.82447 & Nimba & Mano & Zennepa & planted with rice in 2009, and again in 2010. & 0 & 1 & 0 \\
\hline 83 & 6.90768 & -8.91815 & & & Zoazoah & AfDE site with cacao, close to tengbhin & 0 & 0 & 1 \\
\hline$|84|$ & 6.81504 & \begin{tabular}{|l|}
-9.18923 \\
$\mid$
\end{tabular} & Bong & Kpelle & Zowenta & town, population 4750 , surrounded by ring of black soil with cacao, coffee, edo, 15 old spots all with cacao, some with rubber and coffee & 1 & 0 & 15 \\
\hline 85 & 7.05099 & -9.46901 & Bong & Kpelle & Koryah & $\begin{array}{l}\text { Large AfDE site on road from Gbarnga to Lofa. Road goes straight through the site. Very black soils. } 60 \text { people live there. Lots of bananas } \\
\text { and plantain, cocoa, kola, avocado, grapefruit, cotton tree }\end{array}$ & 1 & & \\
\hline 86 & 7.59821 & -9.58615 & Lofa & Gissima Loma & Bacurtazi & $\begin{array}{l}\text { Old town spot for Wenwuta quarter. Large site area planted with cocoa, kola, cotton tree. Middens mixed in with non midden areas. Two } \\
\text { adjacent rice fields possibly on AfDE, while kitchen area with AfDE surrounding it is close }\end{array}$ & 0 & 0 & \\
\hline 87 & 7.61687 & -9.54864 & Lofa & Gissima Loma & Yarwaluwu & Satellite village for Wennwuta, used to be much larger. AfDE site adjacent. 1 rice field, 1 coco farm & 0 & 1 & \\
\hline 88 & 7.63099 & -9.56697 & Lofa & Gissima Loma & Wizita & small village, AfDE around it with fruit trees & 1 & 0 & 0 \\
\hline 89 & 7.63322 & -9.53582 & Lofa & Gissima Loma & Volowozu & village with AfDE surrounding it, plantain, orange cocoa etc. & 1 & 0 & 0 \\
\hline 90 & 7.63474 & -9.5379 & Lofa & Gissima Loma & Volowozu Old & old spot for Volowozu, planted with cocoa, kola and cotton trees & 0 & 0 & 1 \\
\hline 91 & 7.63285 & -9.58962 & Lofa & Gissima Loma & Yankea & village, 1 old spot with cocoa & 0 & 0 & \\
\hline 92 & 7.62726 & -9.60118 & Lofa & Gissima Loma & Makesu & village, 2 old spot with cocoa & 0 & 0 & 2 \\
\hline 93 & 7.6656 & -9.51335 & Lofa & Gissima Loma & Babazu & $\begin{array}{l}\text { Hilltop site with AfDE on side of hill with young fallow. Was planted with veg, some banana. Old town spot with cotton tree, ciciam coffee } \\
\text { in middle. Owners are not related to previous occupants (unusual), who left in owners grandfathers' time. Also with sacrificial stones, } \\
\text { graves }\end{array}$ & 0 & 0 & \\
\hline 94 & 7.66654 & -9.51911 & Lofa & Gissima Loma & Betewalazu & village, surrounded with AfDE, fruit trees & 1 & 0 & 0 \\
\hline 95 & 7.6629 & -9.52842 & Lofa & Gissima Loma & Borlorwotorsu & village, surrounded with AfDE, fruit trees & 1 & 0 & 0 \\
\hline 96 & 8.01506 & 9.44038 & Lofa & Gissima Loma & Kpassagissia & $\begin{array}{l}\text { On border with Guinea, population } 7000 \text {. Town historically on hill, with dump areas extending down the hill. Now the town has spilt down } \\
\text { the hillside and therefore the AfDE has houses on it. Small gardens of plantain and coffee. Women planting small patches of onion. }\end{array}$ & 1 & 0 & 0 \\
\hline 97 & 7.90792 & 9.58751 & Lofa & Gissima Loma & Boi & $\begin{array}{l}\text { Population } 5000+\text {. Large area of AfDE. Ring } 0.5 \mathrm{~km} \text { thick where we observed it. Town has extended onto AfDE, so some small kitchen } \\
\text { gardens on it. AfDE planted with cacao, and with secret society area. Man noted that not all AfDE was dump, but also old fields that had } \\
\text { been cultivated many times. }\end{array}$ & 1 & 0 & 0 \\
\hline 98 & 7.96424 & 9.46238 & Lofa & Gissima Loma & Wakesu & coffee & 0 & 0 & 0 \\
\hline 99 & 7.96424 & 9.46238 & Lofa & Gissima Loma & Wakesu old & cofee & 0 & 0 & \\
\hline 100 & 7.76459 & 9.43176 & Lofa & Gissima Loma & Zorzor & $\begin{array}{l}\text { AfDE under town, used for kitchen gardens } \\
\end{array}$ & 0 & 0 & 0 \\
\hline 101 & & & & & Total & & 26 & 32 & 94 \\
\hline
\end{tabular}




\section{Appendix 2: Transect site descriptions}

\begin{tabular}{|c|c|c|c|}
\hline Location & Soil & Site Description and History & \#Transects \\
\hline Bacurtazi & AfDE & $\begin{array}{l}\text { It is claimed that Bacurtazi was established when a woman from the } \\
\text { Delema quarter married a man from Zolowo. Delema people had been } \\
\text { farming in the Bacurtazi area before the town was established, and the man } \\
\text { from Zolowo decided to found the village in this area. Bacurtazi was } \\
\text { abandoned within living memory, and its inhabitants then moved to a new } \\
\text { spot nearby which, after being a village for decades, is now reduced to four } \\
\text { farm kitchens after being destroyed during the war. }\end{array}$ & 5 \\
\hline Baema & Oxisols & $\begin{array}{l}\text { This is an area of secondary forest } 45-55 \text { years in age. The reason for such a } \\
\text { distance to Wenwuta is that this was identified by elders as the 'oldest' } \\
\text { forest within a day's walk from Wenwuta. However, upon inspection } \\
\text { Diabate concluded it was younger than the Wotizi forests close to } \\
\text { Wenwuta. Even in this sparsely populated area we found mature Kola trees } \\
\text { in the secondary forest. }\end{array}$ & 3 \\
\hline Dadazu & AfDE & This the oldspot for the current village of Dadazu & 2 \\
\hline Delema & AfDE & $\begin{array}{l}\text { Delema is actually now under the authority of the chief of a nearby village, } \\
\text { Karwalawuta. Delema had been haunted by an evil spirit and therefore } \\
\text { Wenwuta people avoided the areas. The chief's father, who had been living } \\
\text { in Monrovia, gained access to the old spot by marrying a woman from } \\
\text { Wenwuta, and then sought permission to plant cacao, kola, coffee, banana } \\
\text { and orange trees there }\end{array}$ & 5 \\
\hline Doyahou & Oxisols & This is an area of secondary forest 50-60 years in age & 5 \\
\hline Famene & AfDE & $\begin{array}{l}\text { Famene belonging to a different ethno-linguistic group, the Barlain-Kpelle } \\
\text { that inhabited the area prior to the arrival of the Loma and therefore so } \\
\text { ancient as to have been long abandoned even in oral histories. Famene, } \\
\text { meaning "hear-hear" in Kpelle (Memene in Loma) (Figure 3) was named as } \\
\text { a place where people from around the region met and discussed issues. }\end{array}$ & 5 \\
\hline Gbokolomie & AfDE & This is the oldspot for the current village of Gbokolomie & 2 \\
\hline Kpazaquelle & AfDE & $\begin{array}{l}\text { This is an oldspot belonging to the town of Tinsue. It has a single male } \\
\text { owner resident in this town. }\end{array}$ & 3 \\
\hline $\begin{array}{l}\text { Wenwuta Old } \\
\text { Spot }\end{array}$ & AfDE & $\begin{array}{l}\text { This is the oldspot for Wenwuta. Wenwuta is dated to } 1670-1682 \text {, implying } \\
\text { this site is long abandoned. Oral histories also contradict. There was no } \\
\text { consensus as to whether this was Wenwuta oldspot, or the oldspot of } \\
\text { Duala, the founding quarter of Wenwuta. Also, it is not clear whether this } \\
\text { site was abandoned and re-occupied or simply abandoned }\end{array}$ & 1 \\
\hline Wotizi 1 & Oxisols & Secondary forest, age $55-65$ years & 7 \\
\hline Wotizi 2 & Oxisols & Secondary forest, age $55-65$ years & 6 \\
\hline Zaioba & AfDE & This is the oldspot for the village of Zaioba & 3 \\
\hline Zelema & AfDE & This is the oldspot for Zelema quarter of Wenwuta & 2 \\
\hline
\end{tabular}


Appendix 3: Soil fertility analysis of 28 composite AfDE samples, one from each transect. Each composite sample was made from 8 subsamples

\begin{tabular}{|c|c|c|c|c|c|c|c|c|c|c|c|c|c|c|c|c|c|c|c|}
\hline Location & \#Transect & Moisture & $\mathrm{pH}$ & pH Buffer & pH 1M KCl & LOI & Organic & Aluminum & Calcium & Copper & Iron & Potassium & Magnesium & Manganese & Phosphorus & Lead & Sulfur & Zink & Calcium \\
\hline & & & & & & & matter & & & & & & & & & & & & \\
\hline & & $\%$ & & & & $\%$ & $\%$ & $\mathrm{mg} / \mathrm{kg}$ & $\mathrm{mg} / \mathrm{kg}$ & $\mathrm{mg} / \mathrm{kg}$ & $\mathrm{mg} / \mathrm{kg}$ & $\mathrm{mmol} / \mathrm{kg}$ & $\mathrm{mg} / \mathrm{Kg}$ & $\mathrm{mg} / \mathrm{kg}$ & $\mathrm{mg} / \mathrm{kg}$ & $\mathrm{mg} / \mathrm{kg}$ & $\mathrm{mg} / \mathrm{kg}$ & $\mathrm{mg} / \mathrm{kg}$ & $\mathrm{mmol} / \mathrm{kg}$ \\
\hline Delema & 1 & 2.06 & 4.91 & 5.29 & 4.45 & 8.65 & 5.82 & 1006.54 & 1887.71 & 3.76 & 208.54 & 70.62 & 110.77 & 60.55 & 12.56 & 1.19 & 15.99 & 3.69 & 471.93 \\
\hline Delema & 2 & 2.22 & 5.28 & 5.92 & 4.76 & 10.09 & 6.83 & 910.14 & 2361.74 & 2.40 & 274.67 & 56.17 & 112.93 & 87.38 & 38.58 & 2.22 & 14.68 & 4.71 & 590.43 \\
\hline Delema & 3 & 5.30 & 5.31 & 5.71 & 4.88 & 11.30 & 7.68 & 785.01 & 3124.50 & 3.50 & 180.21 & 67.24 & 135.89 & 129.35 & 12.81 & 1.67 & 16.83 & 4.72 & 781.12 \\
\hline Delema & 4 & 1.94 & 5.02 & 5.42 & 4.27 & 8.80 & 5.93 & 1193.71 & 1056.28 & 2.82 & 233.72 & 41.11 & 92.09 & 53.65 & 37.37 & 0.69 & 14.02 & 18.49 & 264.07 \\
\hline Delema & 5 & 2.53 & 4.82 & 4.86 & 4.1 & 10.73 & 7.28 & 1258.19 & 1087.45 & 2.45 & 264.62 & 83.03 & 147.90 & 75.72 & 18.29 & 0.29 & 14.29 & 4.48 & 271.86 \\
\hline Wenwuta Old Spot & 6 & 1.32 & 4.51 & 5.64 & 3.83 & 8.03 & 5.39 & 1081.37 & 207.00 & 2.33 & 491.94 & 68.45 & 39.56 & 48.24 & 15.38 & 0.27 & 18.80 & 1.24 & 51.75 \\
\hline Bacurtazi & 7 & 1.53 & 4.81 & 5.37 & 4.42 & 6.61 & 4.40 & 908.14 & 1430.31 & 2.80 & 360.28 & 67.45 & 133.23 & 42.64 & 30.77 & 2.76 & 15.21 & 2.67 & 357.58 \\
\hline Bacurtazi & 8 & 0.99 & 4.44 & 4.9 & 3.77 & 5.77 & 3.81 & 912.96 & 316.86 & 3.64 & 481.34 & 60.43 & 62.79 & 36.96 & 15.63 & 0.69 & 12.91 & 2.78 & 79.21 \\
\hline Bacurtazi & 9 & 0.72 & 4.67 & 4.93 & 3.94 & 5.19 & 3.41 & 988.75 & 272.04 & 2.79 & 384.59 & 33.76 & 44.19 & 48.31 & 19.62 & 0.84 & 13.94 & 2.29 & 68.01 \\
\hline Bacurtazi & 10 & 1.09 & 4.66 & 4.82 & 3.92 & 5.62 & 3.71 & 1230.78 & 230.01 & 2.47 & 405.77 & 39.93 & 35.37 & 60.59 & 24.15 & 0.01 & 16.47 & 2.93 & 57.50 \\
\hline Bacurtazi & 11 & 1.04 & 4.25 & 5.01 & 3.81 & 5.37 & 3.53 & 884.93 & 223.64 & 2.62 & 254.35 & 38.26 & 44.26 & 20.74 & 9.24 & 0.95 & 16.72 & 1.97 & 55.91 \\
\hline Famene & 12 & 1.62 & 4.63 & 5.15 & 4.2 & 8.99 & 6.06 & 1102.84 & 797.52 & 2.44 & 273.59 & 102.23 & 92.53 & 64.12 & 13.07 & 0.63 & 18.82 & 3.48 & 199.38 \\
\hline Famene & 13 & 2.56 & 5.54 & 5.89 & 5.04 & 10.22 & 6.93 & 997.13 & 1959.55 & 2.39 & 167.94 & 67.05 & 377.99 & 42.94 & 16.58 & 0.79 & 13.69 & 3.10 & 489.89 \\
\hline Famene & 14 & 2.80 & 4.8 & 5.51 & 4.22 & 8.97 & 6.05 & 1027.78 & 852.84 & 2.43 & 280.36 & 88.99 & 94.01 & 74.85 & 15.96 & 1.09 & 18.68 & 2.42 & 213.21 \\
\hline Famene & 15 & 1.27 & 4.64 & 5.69 & 4.25 & 6.55 & 4.36 & 638.74 & 866.76 & 1.41 & 180.07 & 61.90 & 79.07 & 31.62 & 6.45 & 1.22 & 13.80 & 1.36 & 216.69 \\
\hline Famene & 16 & 1.28 & 4.92 & 5.37 & 4.28 & 8.51 & 5.73 & 981.29 & 744.08 & 2.13 & 329.61 & 68.87 & 101.55 & 76.72 & 16.61 & 1.00 & 16.62 & 1.86 & 186.02 \\
\hline Gbokolomie & 17 & 1.67 & 4.91 & 4.97 & 4.12 & 7.87 & 5.28 & 1390.16 & 636.99 & 4.31 & 258.95 & 48.23 & 104.55 & 78.02 & 62.02 & 0.00 & 12.18 & 4.67 & 159.25 \\
\hline Gbokolomie & 18 & 1.72 & 4.83 & 4.88 & 4.15 & 8.28 & 5.56 & 1078.82 & 939.57 & 3.14 & 298.02 & 52.02 & 88.02 & 51.20 & 20.98 & 0.26 & 15.23 & 2.93 & 234.89 \\
\hline Dadazu & 19 & 1.66 & 4.21 & 4.8 & 3.77 & 7.19 & 4.80 & 1151.01 & 417.14 & 2.28 & 238.86 & 38.41 & 68.38 & 20.81 & 11.79 & 0.36 & 18.35 & 1.81 & 104.28 \\
\hline Dadazu & 20 & 1.59 & 4.08 & 4.44 & 3.73 & 6.14 & 4.07 & 1219.35 & 339.89 & 3.31 & 280.41 & 37.17 & 25.21 & 68.63 & 23.51 & 0.00 & 14.30 & 3.54 & 84.97 \\
\hline Zelema & 21 & 1.62 & 4.71 & 5.19 & 4.09 & 9.20 & 6.21 & 1038.14 & 769.73 & 2.55 & 292.98 & 41.45 & 60.29 & 74.05 & 19.10 & 1.80 & 12.14 & 2.71 & 192.43 \\
\hline Zelema & 22 & 1.91 & 4.65 & 5.25 & 4.19 & 11.01 & 7.48 & 1025.33 & 1289.25 & 3.00 & 210.11 & 49.42 & 60.14 & 64.71 & 13.55 & 3.33 & 12.13 & 1.63 & 322.31 \\
\hline Zaioba & 23 & 1.39 & 4.43 & 4.69 & 3.85 & 8.14 & 5.46 & 997.24 & 375.97 & 2.67 & 392.31 & 52.28 & 97.55 & 58.79 & 15.05 & 2.13 & 13.34 & 2.03 & 93.99 \\
\hline Zaioba & 24 & 1.71 & 4.52 & 4.7 & 3.93 & 9.56 & 6.46 & 1029.49 & 548.57 & 4.76 & 340.33 & 57.22 & 91.82 & 49.68 & 6.98 & 2.32 & 14.71 & 2.54 & 137.14 \\
\hline Zaioba & 25 & 1.10 & 4.59 & 4.7 & 3.97 & 7.34 & 4.91 & 935.28 & 455.16 & 4.83 & 325.84 & 39.68 & 68.29 & 42.45 & 10.16 & 2.12 & 16.30 & 1.21 & 113.79 \\
\hline Kpazaquelle & 26 & 1.66 & 4.91 & 5.32 & 4.42 & 8.00 & 5.37 & 1033.46 & 1290.00 & 2.80 & 216.43 & 41.13 & 100.19 & 95.84 & 19.02 & 2.65 & 12.75 & 4.17 & 322.50 \\
\hline Kpazaquelle & 27 & 1.74 & 4.9 & 5.5 & 4.28 & 8.71 & 5.86 & 1047.65 & 1088.71 & 2.28 & 199.98 & 45.08 & 83.00 & 86.60 & 11.87 & 3.24 & 12.21 & 2.01 & 272.18 \\
\hline Kpazaquelle & 28 & 3.23 & 5.02 & 5.56 & 4.61 & 10.36 & 7.02 & 1010.25 & 2556.67 & 4.50 & 188.26 & 47.48 & 68.43 & 138.51 & 21.21 & 2.75 & 14.16 & 4.71 & 639.17 \\
\hline
\end{tabular}

